\title{
FY2021-Output Cost Estimates and Budget Outturn
}




\section{INTERNATIONAL MONETARY FUND}

October 2021

\section{FY2021—OUTPUT COST ESTIMATES AND BUDGET OUTTURN}

IMF staff regularly produces papers proposing new IMF policies, exploring options for reform, or reviewing existing IMF policies and operations. The Report prepared by IMF staff and completed on September 8, 2021, has been released.

The staff report was issued to the Executive Board for information. The report was prepared by IMF staff. The views expressed in this paper are those of the IMF staff and do not necessarily represent the views of the IMF's Executive Board.

The IMF's transparency policy allows for the deletion of market-sensitive information and premature disclosure of the authorities' policy intentions in published staff reports and other documents.

Electronic copies of IMF Policy Papers

are available to the public from

http://www.imf.org/external/pp/ppindex.aspx

International Monetary Fund

Washington, D.C. 


\section{INTERNATIONAL MONETARY FUND}

September 8, 2021

\section{FY2021—OUTPUT COST ESTIMATES AND BUDGET OUTTURN}

\section{EXECUTIVE SUMMARY}

The COVID-19 pandemic and the ensuing global economic crisis had profound effect on the Fund's members and on its own operations during FY21, with multispeed, incomplete recoveries underway amid high uncertainty. A prompt reallocation of resources and use of contingencies facilitated an agile response by the Fund to the needs of the membership.

This paper details the final FY21 outturn. It highlights the timely reprioritization of activities and repurposing of resources to address crisis-related needs within the flat real budget envelope. At the same time, the Fund addressed operational needs related to business continuity in the context of the work-from-home environment and a travel moratorium.

Lower utilization of the net administrative budget (94.9 percent compared to 99.3 percent in FY20) primarily reflected the travel moratorium and the impact of lower building occupancy and IT-related shortfalls. A pandemic-related drop in CD-related travel and personnel spending likewise drove a decline in externally financed execution from 84 percent in FY20 to just under 60 percent. Similarly, capital budget utilization fell to 41 percent from 54 percent in FY20 due to crisis-driven postponement of several projects, particularly related to facilities.

Importantly, spending data does not reflect the significant increase in uncompensated work from overtime and unused leave during FY21.

In April 2021, the Executive Board approved a temporary increase in the general carry forward limit from 5 to 8 percent of the net administrative budget, allowing use of underspend from previous years to meet transitional and crisis-related needs in FY22 and future years, including for a temporary ramp up in staffing.

In the coming period, the Fund's budget will continue to be affected by the crisisrelated needs of the membership, as well as the impact of longer-term challenges affecting the global economy, including climate change, digitalization and increasing divergence between and within member countries. Likewise, future budgets will incorporate ongoing modernization and new ways of working, drawing from lessons from the crisis period. 
Approved By

Michele Shannon
Prepared by an Office of Budget and Planning (OBP) team led by Maria Albino and Barrie Williams under the supervision of Emre Alper with contribution from Feras Abu Amra, Gillian Adu, Anand Balakrishnan, Raquel Chuayffet, Angeliki Economopoulos, Cher Huo, Mathew Madsen, Mercy Pinargote, Delano Radgman, Axel Schimmelpfennig, Anika Shtuni, Justin Tyson, and Muriel Vimond.

See Annex II on Capacity Development for additional authors.

\section{CONTENTS}

Abbreviation and Acronyms 4

FY2021 HIGHLIGHTS 6

SECTION I. OVERVIEW 7

SECTION II. SPENDING BY OUTPUTS 10

A. Spending by Output Areas 10

B. Spending by Department $\underline{16}$

C. Spending by Priority Topics $\underline{17}$

SECTION III. SPENDING BY INPUTS 19

A. By Major Budget Category $\underline{19}$

SECTION IV. CAPITAL SPENDING $\underline{23}$

\section{BOXES}

1. The Fund's Agile Response to the COVID Crisis_____ $\underline{8}$

2. Heightened Work Pressures on Staff___ $\underline{9}$

3. Staff Hours and Fund Output__ 11

\section{FIGURES}

1. Fund Outputs, FY21 $\underline{10}$

2. Spending on Lending Activities, FY21 $\underline{12}$

3. Spending in Bilateral Surveillance $\underline{12}$

4. Spending on Capacity Development, FY17-21 $\underline{13}$

5. Spending per Country, FY21 vs FY20 $\underline{14}$ 
6. Average Spending by Income Level, FY21 __ 14

7. Multilateral Surveillance, Analytical and Policy Work__ 15

8. Change in Outputs by Department, FY21 vs FY20 _ـ 17

9. Spending by Department Type and Outputs, FY21__ 17

10. Spending on Priority Topics, FY21__ 18

11. Trends in Personnel Spending ___ 20

12. Fund-Financed Buildings and Other, FY19-21__ 22

13. Security-Related Spending, FY19-21__ 22

14. IT Capital Expenditure, FY21__ 23

15. Facilities Capital Expenditure, FY21___ 24

\section{TABLES}

1 Overview of Administrative Budget and Expenditures, FY20-21___ $\underline{7}$

2. Administrative Budget and Expenditures, FY20-21__ 19

3. Travel, FY19-21_ $\underline{21}$

4. Receipts, FY19-21_ $\underline{22}$

5. Capital Expenditures, FY20-21__ $\underline{23}$

\section{ANNEXES}

I. Technical Annex-Concepts and Methodologies__ $\underline{25}$

II. Capacity Development___ $\underline{26}$

III. Statistical Tables__ $\underline{32}$ 


\section{Abbreviation and Acronyms}

\begin{tabular}{|c|c|}
\hline ACES & Analytic Costing and Estimation System \\
\hline$A D$ & Area Departments \\
\hline AFR & African Department \\
\hline APD & Asia \& Pacific Department \\
\hline CCAM & Caucasus, Central Asia, and Mongolia \\
\hline CCAMTAC & Caucasus, Central Asia, and Mongolia Technical Assistance Center \\
\hline CCBR & Comprehensive Compensation and Benefits Review \\
\hline CD & Capacity Development \\
\hline CDFF & Capacity Development Fund-financed \\
\hline CDEF & Capacity Development Externally financed \\
\hline CDMAP & Capacity Development Management and Administration Program \\
\hline COM & Communications Department \\
\hline CSR & Comprehensive Surveillance Review \\
\hline ECF & Extended Credit Facility \\
\hline EFF & Extended Fund Facility \\
\hline FAD & Fiscal Affairs Department \\
\hline FCS & Fragile and Conflict-Affected States \\
\hline FGF & Fund Governance and Fund Finances \\
\hline FIN & Finance Department \\
\hline FSAP & Financial Sector Assessment Program \\
\hline FTE & Full-Time Equivalent \\
\hline GED & Global External Deflator \\
\hline GPA & Global Policy Agenda \\
\hline GRA & General Resource Account \\
\hline HRD & Human Resources Department \\
\hline ICD & Institute for Capacity Development \\
\hline iDW & Integrated Digital Workplace \\
\hline IEO & Independent Evaluation Office \\
\hline ISU & Internal Support \\
\hline LEG & Legal Department \\
\hline LOE & Lending including other engagement \\
\hline MCD & Middle East \& Central Asia Department \\
\hline MCM & Monetary and Capital Markets Department \\
\hline MSAP & Multilateral Surveillance, Analytical, and Policy Work \\
\hline MTB & Medium-Term Budget \\
\hline OBP & Office of Budget and Planning \\
\hline OED & Office of Executive Directors \\
\hline PFTAC & Pacific Financial Technical Assistance Centre \\
\hline PRGT & Poverty Reduction and Growth Trust \\
\hline RCF & Rapid Credit Facility \\
\hline
\end{tabular}




$\begin{array}{ll}\text { RES } & \text { Research Department } \\ \text { RFI } & \text { Rapid Financing Instrument } \\ \text { RTAC } & \text { Regional Training Assistance Center } \\ \text { SBA } & \text { Stand-By Arrangement } \\ \text { SCF } & \text { Stand-By Credit Facility } \\ \text { SEC } & \text { Secretary's Department } \\ \text { SPR } & \text { Strategy, Policy, and Review Department } \\ \text { STA } & \text { Statistics Department } \\ \text { SU } & \text { Bilateral Surveillance } \\ \text { TFMF } & \text { Trust Fund Management Fee } \\ \text { TRACES } & \text { Time Reporting for Analytic Costing and Estimation System } \\ \text { WHD } & \text { Western Hemisphere Department }\end{array}$




\section{FY2021 HIGHLIGHTS}

94.9 percent utilization of the $\$ 1.186$ billion net administrative budget.

$\$ 1.126 b$

Total net administrative expenditures

\section{8}

\section{Lending operations}

Including 43 approvals of emergency financing.

Engagement with members via virtual missions, with a near total pause in travel due to the crisis.

\section{6 in-person missions}

$\$ 88.4 m$

\section{General carry forward}

58 percent utilization of available externally financed budget.
Available for temporary crisis-related need in FY22 and the medium term.
$\$ 77 m$

Capital spending
About two thirds of which went to IT-supported projects, mainly modernization projects and prerequisites.

\section{Spending by Outputs}

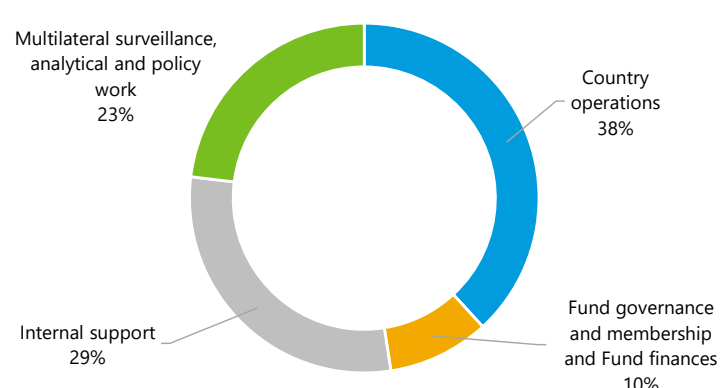

Spending by inputs

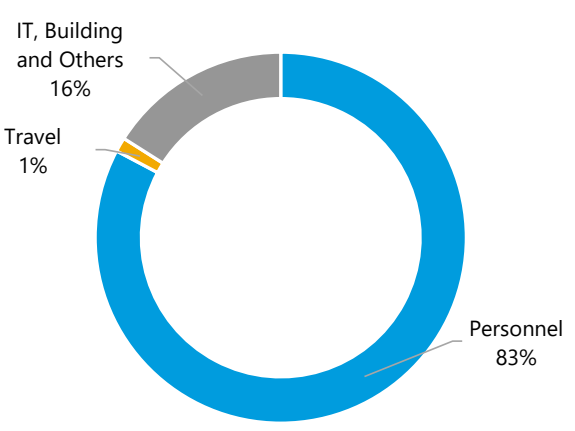




\section{SECTION I. OVERVIEW}

1. Global crisis and divergent recovery. With the outbreak of the COVID-19 pandemic in the last two months of FY20, the Fund's work shifted in FY21 to crisis response, in line with the priorities in the April 2020 GPA. As global conditions began to improve, the Fund's work supported members in transitioning towards a durable exit from the crisis, and in addressing longer-term challenges that will shape the global economy in future years, consistent with the October 2020 GPA.

2. Agile response (Box 1). Staff were redeployed to meet the priority needs of the membership, and operational teams supported the shift to remote work arrangements and the health and safety related needs for staff stemming from the crisis. Savings from travel and deferred activities, contingencies, as well as additional carry forward resources authorized in the FY21 budget process, were deployed over the course of the year to support a temporary ramp-up in staffing and address crisis-related operational needs. The year was also marked by acute work pressures, with a sharp increase in staff overtime and decline in leave usage (Box 2). The work-from-home environment aggravated these pressures, especially for families with school-age children.

3. Budget utilization (Table 1). Execution of the net administrative budget fell to 94.9 percent (\$1,126 million) in FY21 from 99.3 percent in FY20, driven by the travel moratorium, low building occupancy (e.g., utilities) and IT-related shortfalls linked to the IT department's reorganization. With reallocation of these resources, lower utilization also reflects the timeline needed to bring on temporary staff authorized during the year, with hiring continuing into FY22. In addition, some emergency reallocations were not, in the end, required. Externally financed execution also fell, from 84.0 percent to 57.5 percent, driven mainly by a fall in CD-related travel and personnel spending triggered by the pandemic.

\begin{tabular}{|c|c|c|c|c|c|c|}
\hline & \multicolumn{3}{|c|}{$\mathrm{FY} 20$} & \multicolumn{3}{|c|}{ FY 21} \\
\hline & Budget & Outturn & $\begin{array}{c}\text { Utilization } \\
\text { (percent) }\end{array}$ & Budget & Outturn & $\begin{array}{c}\text { Utilization } \\
\text { (percent) }\end{array}$ \\
\hline Total gross expenditures & 1,397 & 1,350 & 96.6 & 1,429 & 1,268 & 88.8 \\
\hline Fund-financed & 1,197 & 1,182 & 98.7 & 1,223 & 1,150 & 94.0 \\
\hline Externally financed $1 /$ & 200 & 168 & 84.0 & 206 & 118 & 57.5 \\
\hline Total net expenditures & 1,158 & 1,150 & 99.3 & 1,186 & 1,126 & 94.9 \\
\hline Of which: Fund-financed & 1,158 & 1,150 & 99.3 & 1,186 & 1,126 & 94.9 \\
\hline Carry forward from previous year & 47 & & & 55 & & \\
\hline Total net available resources & 1,205 & 1,150 & 95.4 & 1,241 & 1,126 & 90.7 \\
\hline $\begin{array}{l}\text { Source: Office of Budget and Plannir } \\
\text { 1/ Based on receipts from donors. Fo } \\
\text { and standard costs for some externa } \\
\text { measures on benefits. }\end{array}$ & $\begin{array}{l}\text { (OBP). } \\
=Y 21, \text { a } \$ \\
\text { funded }\end{array}$ & $\begin{array}{l}\text { million a } \\
\text { rsonnel e }\end{array}$ & $\begin{array}{l}\text { Istment re } \\
\text { enditures }\end{array}$ & reconci & on betwe & n actual \\
\hline
\end{tabular}


4. Carry forward. The general carry forward moving into FY22 will be at the temporary limit of 8 percent (\$88.4 million) set by the Executive Board in April 2021, providing additional space to meet temporary crisis needs. An additional $\$ 8.3$ million is also available for general use in FY22 from underspend in FY21 above separate limits for the Office of Executive Directors (OED) and the Independent Evaluation Office (IEO). ${ }^{1}$

\section{Box 1. The Fund's Agile Response to the COVID Crisis}

Crisis response. Initial crisis needs were met through reprioritization; deferral of non-crisis work; streamlining of procedures; and informal, temporary reassignment of some 60 staff to member-facing departments and others with crisis-related work pressures (Supplemental FY21-23 MTB). Departmental Accountability Frameworks and underlying objectives were updated in the summer, supporting updated allocations within the existing budget envelope. Space for priority needs was based on:

- Repurposing travel and events budgets. About 95 percent of business travel resources and 90 percent of event resources were reallocated to crisis needs, with a buffer maintained centrally given in-year uncertainty on travel resumption. The suspension affected country work, seminars, recruitment, and settlement.

- Reprioritization/savings. Key measures included a six-month pause in Article IVs and FSAPs, refocusing $C D$ on crisis-related issues, suspending non-crisis analytical and policy work (e.g., CSR and FSAP Reviews), postponing conferences, and adoption of simplified processes, including for approval of emergency financing cases.

\section{Distribution of Crisis Positions}

- 74 Direct country support in Area Departments, FAD, LEG, MCM, SPR.

- 42 Review and policy/analytical work on crisis issues (SPR, LEG, FIN, COM, RES).

- $12 \mathrm{SEC} /$ Risk/Other small offices

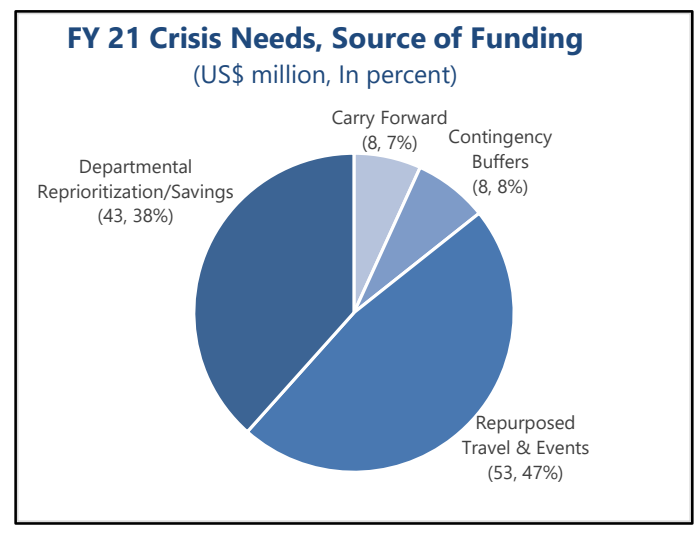

- Emergency buffers and a larger carry forward. Additional resources from the increase in the FY20 carry forward limit from 3 to 5 percent, approved by the Board in April 2020, and existing contingencies were used to address remaining immediate crisis needs.

- Addressing emergency needs. The mobilization of resources funded allocation of 128 temporary crisis positions (about 5 percent of staff), with hiring continuing into FY22. These positions to be phased out as crisis needs recede. In addition, the mobilized resources have been used for evacuations, HQ preparation for a safe return to the office, staff support for remote working, and provisions for revenue losses (e.g., parking, the Concordia).

${ }^{1} \mathrm{FY} 21$ carry forward for OED and IEO are $\$ 12.7$ million and $\$ 0.5$ million, respectively. 


\section{Box 2. Heightened Work Pressures on Staff}

Work pressures increased as staff responded to emergence of crisis-related needs at a time when staff resources were already stretched. The work-from-home environment added to this challenge, particularly for staff with young children. In the December 2020 staff survey, 41 percent of staff reported that they struggled to maintain work-life balance.

- Recorded staff time on main outputs increased by 5 percent relative to the average in the three years prior to the crisis. This reflects the ramp up of work on lending (up 27 percent), and multilateral surveillance/analytical and policy work (up 14 percent). An increase in work on Fund governance and finances (8 percent) and internal support ( 5 percent) also addressed challenges to the Fund operations created by the crisis. These changes were partly offset by less time devoted to bilateral surveillance (down 14 percent), reflecting the shift in time by country and review teams to lending. $C D$ also dropped by (6 percent), reflecting a decline in externally funded $C D$.

- Overtime and Annual Leave. Departments experienced an increase in average overtime of 26 percent relative to FY20. Uncompensated overtime accounted for 91 percent of the Fund-wide average overtime increase. The rise in overtime is broad-based across departments. Use of annual leave fell by 39 percent Fund-wide, also reflecting travel restrictions. Staff training also dropped by some 30 percent.

\section{Fund-wide Overtime and Annual leave}

Average Fund-wide Overtime Rate Past 2 Years Average Annual Leave, FY21 May-Apr (Days)

(Staff only, percent)
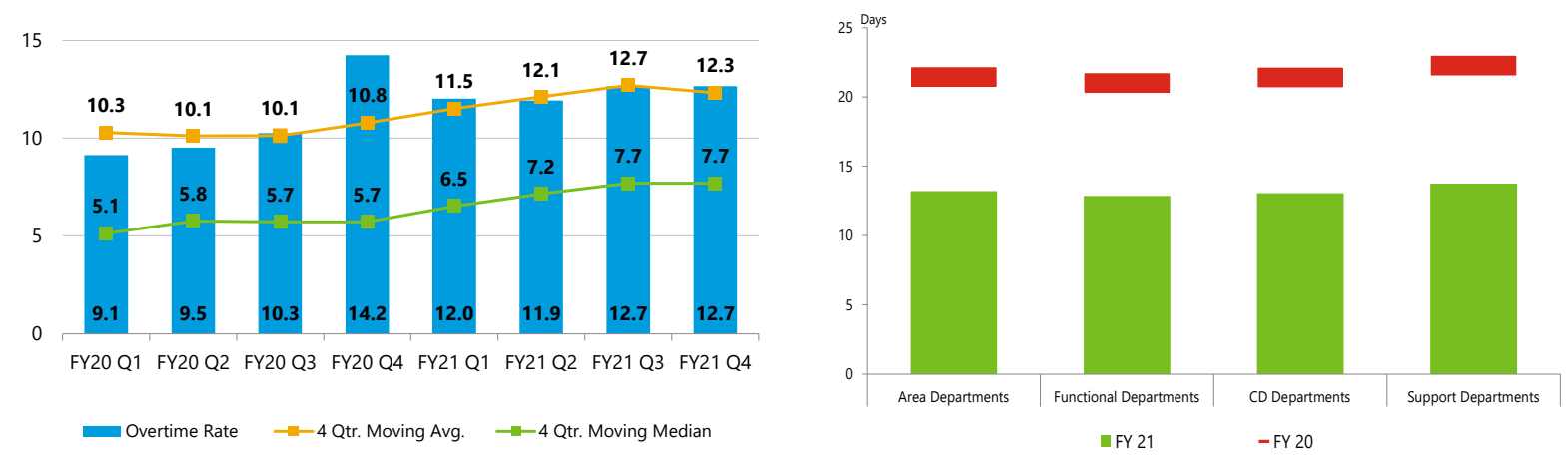
5. Roadmap. Section II presents spending by key output areas, priority topics, and department. Section III discusses spending by key input categories. Section IV reports on the implementation of the capital budget. Annex I presents key budget concepts and methodologies; Annex II, prepared by ICD, details CD activities; and Annex III presents key budget statistics.

\section{SECTION II. SPENDING BY OUTPUTS}

\section{A. Spending by Output Areas}

6. Focus on crisis work (Figure 1). Given the travel moratorium, all spending numbers in both FY20 and FY21 in this and the next section exclude travel. Spending related to lending increased by 19 percent ( $\$ 23$ million) year-on-year, with a parallel drop in spending on bilateral surveillance of 15 percent ( $\$ 28$ million) in light of the crisis-driven shift in country needs. A 16 percent ( $\$ 33$ million) drop in direct $C D$ delivery was driven by externally financed $C D$, which dropped 26 percent ( $\$ 30$ million). This in turn was driven by the travel-related drop in employment of field-based shortterm experts. Spending on multilateral surveillance, analytical and policy work also expanded by 5 percent ( $\$ 13$ million), driven by crisis-related activities. These figures do not provide a full measure of changes in staff work, however, given the significant increase in staff overtime, a decline in leave usage, and a drop in average staff costs (Box 3).

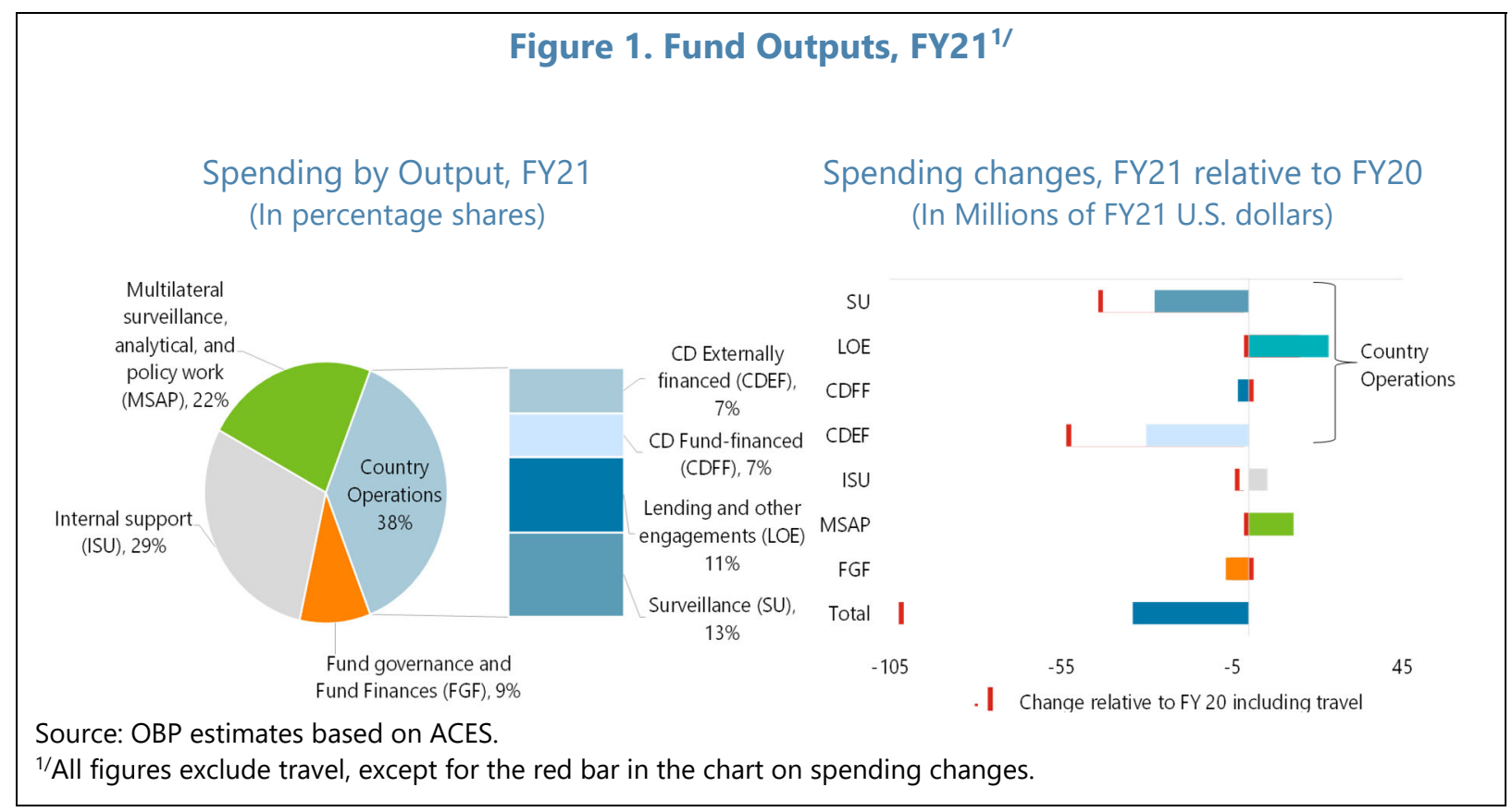




\section{Box 3. Staff Hours and Fund Output ${ }^{1 /}$}

Measurement. Measuring total Fund output through gross spending in constant prices, of which over 80 percent is personnel spending, understates actual output and complicates year-on-year comparisons in cases where i) unit cost of personnel spending declines in real terms, as occurred in FY21 and ii) there is an increase in uncompensated overtime or decline in leave usage. As such, reference to total staff hours, while having some limitations given gaps in the self-reporting system, provides complementary output information which controls for these issues.

Overtime had a significant effect on output. Total staff time increased by 4 percent from FY20, with overtime contributing 30 percent. Increased time on lending activities (27 percent) more than balanced a decline in surveillance activities. A decline in $C D$ was driven by externally funded operations. Overall, the increase in uncompensated overtime from FY20 to FY21 is equivalent to 37 FTEs, about $\$ 12$ million. This increase in FY21 comes on the heels of an increase in uncompensated overtime, equivalent to $15 \mathrm{FTEs}$, about $\$ 5$ million, from FY19 to FY20, reflecting the start of the pandemic related work in the last two months of FY20.

\section{Fund Outputs ${ }^{1 /}$}

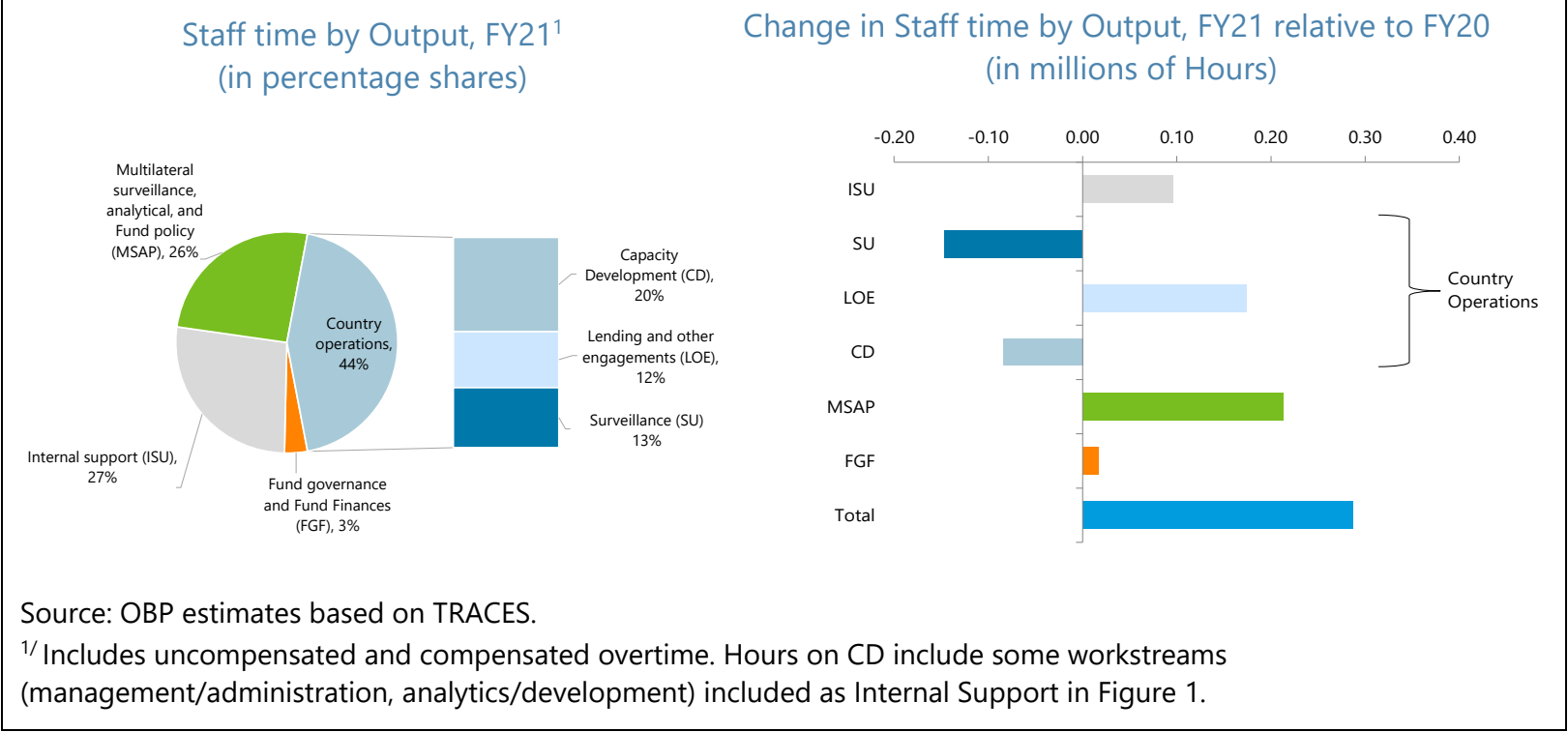

7. Country Operations. Gross spending on country operations, excluding travel, declined by 7 percent ( $\$ 36$ million) and by 1 percentage point as a share of total spending relative to FY20. Excluding externally funded $C D$, country spending declined by 2 percent ( $\$ 8$ million).

- The increase in spending related to lending was driven by emergency financing operations (RFI in non-concessional and RCF in concessional financing assistance). Work on these issues rose by 325 percent ( $\$ 54$ million). The Board approved 43 emergency lending operations in FY21, adding to 40 operations approved in the last two months of FY20. Spending related to work on financial assistance through other facilities, including the Flexible Credit Line (FCL) and Precautionary Liquidity Line (PLL), as well as augmentations to existing concessional Fund programs also increased by 13 percent ( $\$ 10$ million). Spending associated with nonconcessional financing declined by 5 percent ( $\$ 3$ million) with greater recourse to emergency lending. 


\section{Figure 2. Spending on Lending Activities, FY21}

Spending Related to Lending by Facility ${ }^{1 /}$

(Direct Costs, Millions of FY21 U.S. dollars)

DFY $20 \square$ FY 21

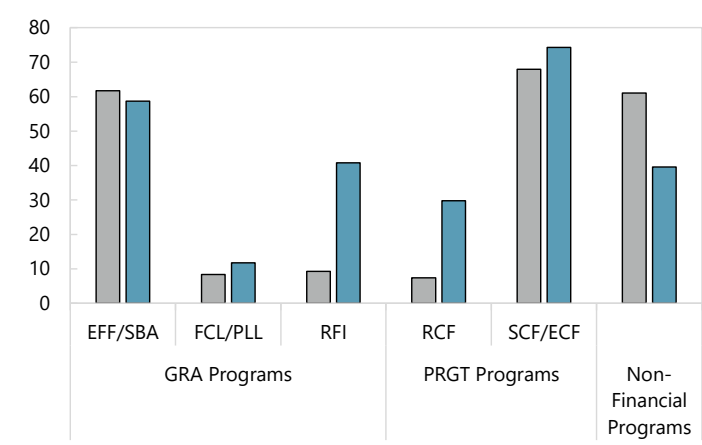

Source: OBP estimates.

1/Excludes travel.
Spending Related to Emergency Financing ${ }^{1 /}$ (Bubble size refers to total access, SDR million)

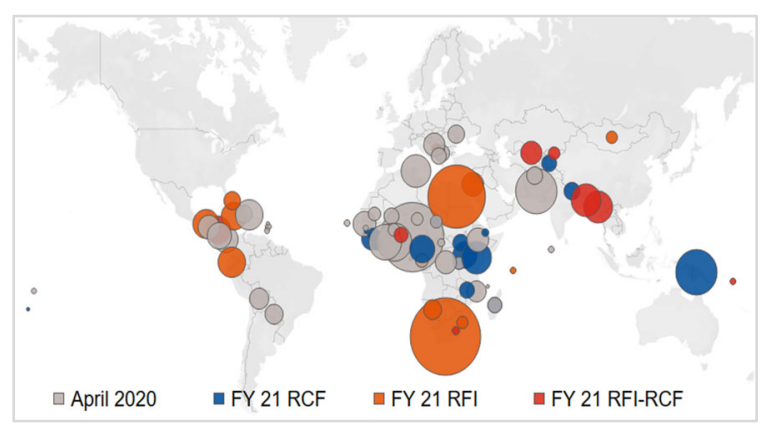

Source: Based on IMF. MONA database

${ }^{1 / E m e r g e n c y ~ f i n a n c i a l ~ a s s i s t a n c e ~ i n ~ F Y 20-21 . ~}$

- $\quad$ Spending on bilateral surveillance (excluding travel) fell by 15 percent ( $\$ 28$ million) driven by the decline in Article IV activities given a temporary suspension in the first part of the year. These activities resumed gradually beginning in July 2020. In total, 36 Article IV consultations were completed, relative 113 in FY20. The average cost of an Article IV Consultation excluding travel declined to about $\$ 0.5$ million (versus $\$ 0.6$ million in FY20), reflecting streamlining of coverage and review procedures. Spending on FSAPs also fell with a temporary suspension in FY21, with five FSAPs completed relative to nine in FY20. Average costs excluding travel remained relatively stable. Other bilateral surveillance increased by 10 percent to $\$ 44$ million, reflecting surveillance activities in countries with Fund arrangements, particularly countries receiving emergency financing. Average costs excluding travel of other bilateral surveillance remained relatively stable.

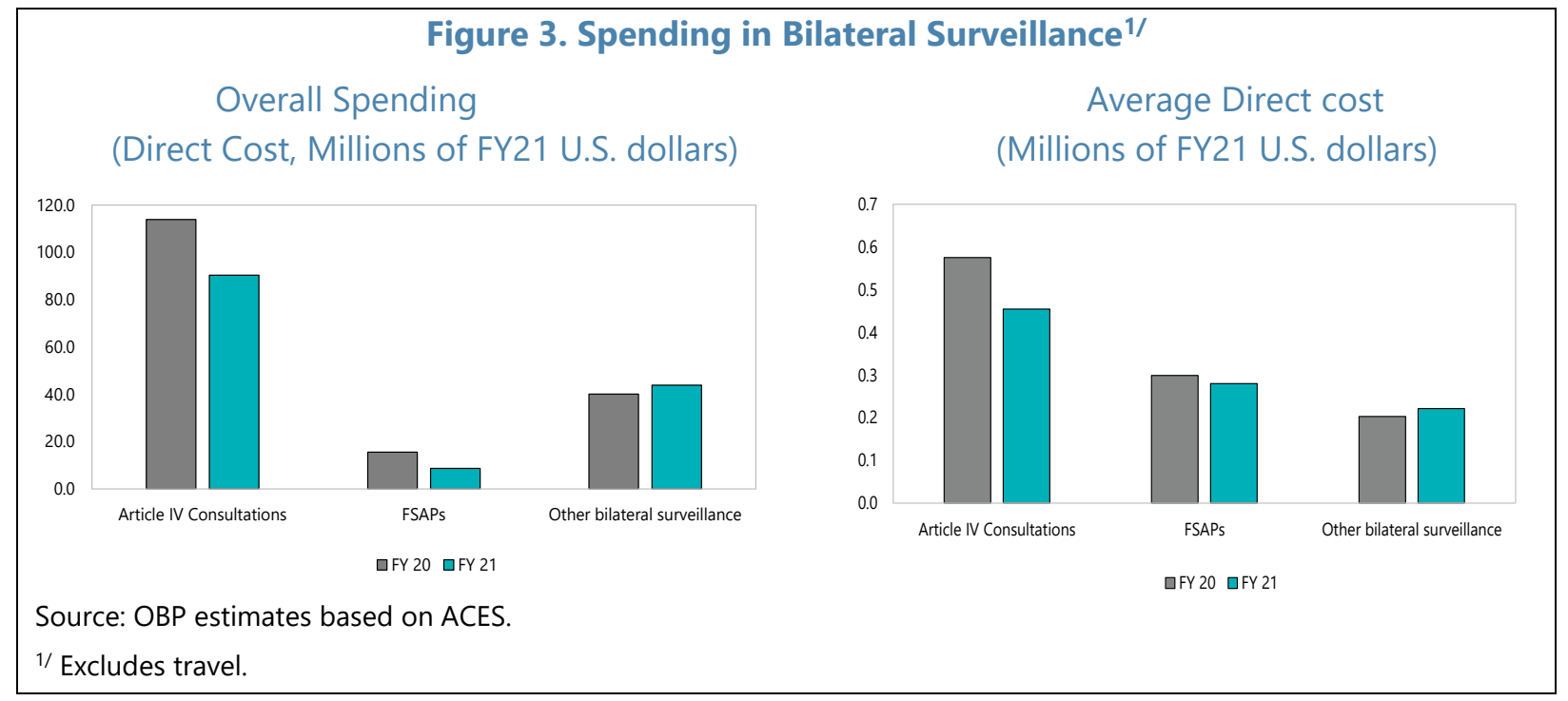


- $\quad$ Capacity Development. Fundfinanced CD spending (\$131 million) was 91 percent of budget and externally financed CD (\$118 million) was just under 60 percent of budgeted levels, mainly reflecting the travel disruption (Annex 2). Overall CD spending declined by $\$ 17$ million (6 percent) relative to $\mathrm{FY} 20$, reflecting a $\$ 1$ million increase in Fund-financed $C D$ and $a$ $\$ 19$ million decline in externally financed CD. Delivery as measured by personnel fell 1 percent overall, with a 2.8 percent increase in Fund-financed CD. Lower externally financed $C D$ delivery had an impact on chargebacks for staff time $\$ 2.7$ million below budget, albeit with the gap lower than the $\$ 4.8$ million estimate early in the year) and Trust Fund Management Fee receipts ( $\$ 6.1$ million below budget), requiring coverage through the Fund's own resources.

$0 \quad$ Relatively high Fund-financed CD utilization reflects greater repurposing towards virtual delivery than donor funds which are somewhat less flexible, and the higher share of Fund versus partner resources used for management and administration, including departmental engagement for development and testing of the improved CD Management and Administration system (CDMAP).

$0 \quad$ All countries receiving emergency financing received $C D$ support. Overall $C D$ demand focused on fiscal (mobilizing revenue, strengthening expenditure management) and monetary and financial sectors (crisis management, bank resolution, debt management, debt transparency, and central banking operations, and governance).

- $\quad$ Average country spending. Overall, average country spending (excluding travel) declined by 8 percent (to $\$ 2.2$ million) relative to $\mathrm{FY} 20$, or 3 percent (to $\$ 1.8$ million) excluding externally funded $C D{ }^{2}$ For surveillance countries, average spending declined by 33 percent (to about $\$ 1$ million), due to lower CD activities and narrower focus on crisis-issues. For countries with intensive surveillance (near program) or program status, average spending declined more moderately, by 20 percent and 8 percent, respectively.

\footnotetext{
${ }^{2}$ Average country spending over FY18-FY20 (including travel) was $\$ 2.3$ million.
} 
Figure 5. Spending per Country, FY21 vs FY201/

(Average Direct cost, Millions of FY21 U.S. dollars)

Spending (excluding travel) declined for all country groups driven largely by externally funded $C D$, except in standard surveillance cases.

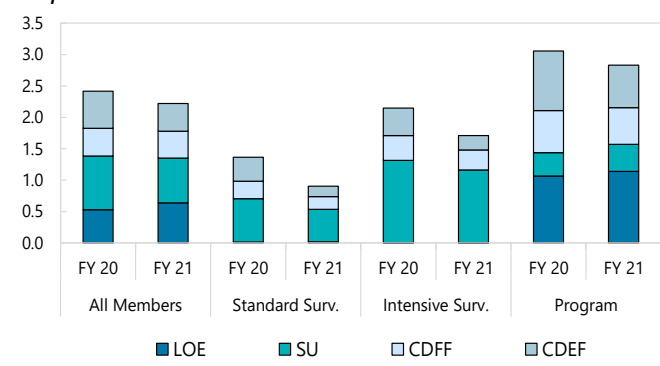

For FCS, lending increased, and Fund-financed $C D$ remained stable. Externally financed $C D$ drove overall spending down.

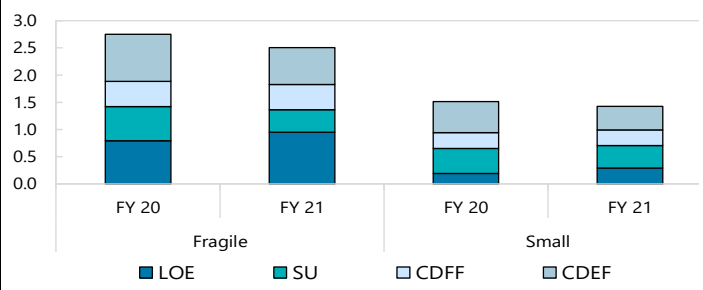

Source: OBP estimates based on ACES.

${ }^{1 /}$ Excludes travel.
Spending for vulnerable program countries fell, as emergency financing involved less intensive use of resources.

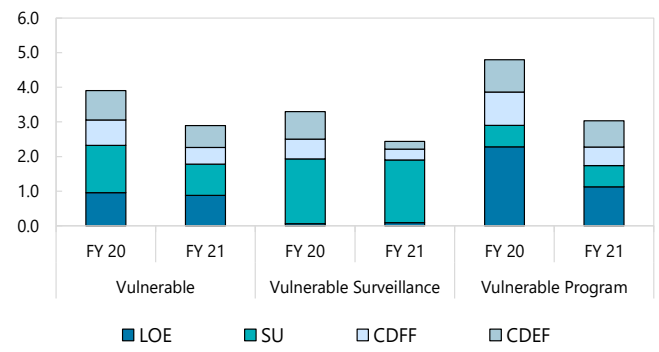

Africa and Asia-Pacific regions faced material declines in average country spending, again driven by lower externally financed $C D$.

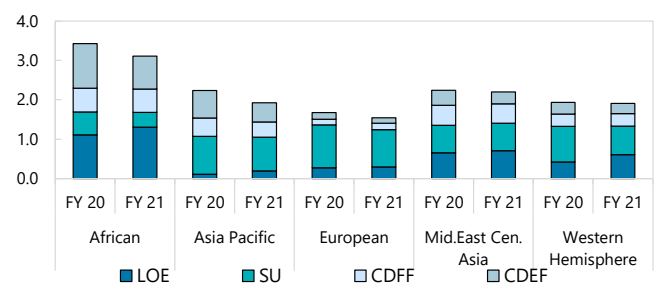

Spending by income level. Average country spending in low incomedeveloping economies, excluding travel, declined by 10 percent to $\$ 3.1$ million, while remaining broadly stable at $\$ 2.2$ million on a net basis (excluding externally funded $C D$ ). In emerging markets, average country spending declined to $\$ 2.1$ million ( $\$ 2.3$ million in FY20) as surveillance and CD activities were less affected. Non-G20 advanced economies experienced the largest declines in average country spending due to delays in surveillance activities, important for this group.
Figure 6. Average Spending by Income Level, FY21 ${ }^{1 /}$

(Direct Cost, Millions of FY21 U.S. dollars)

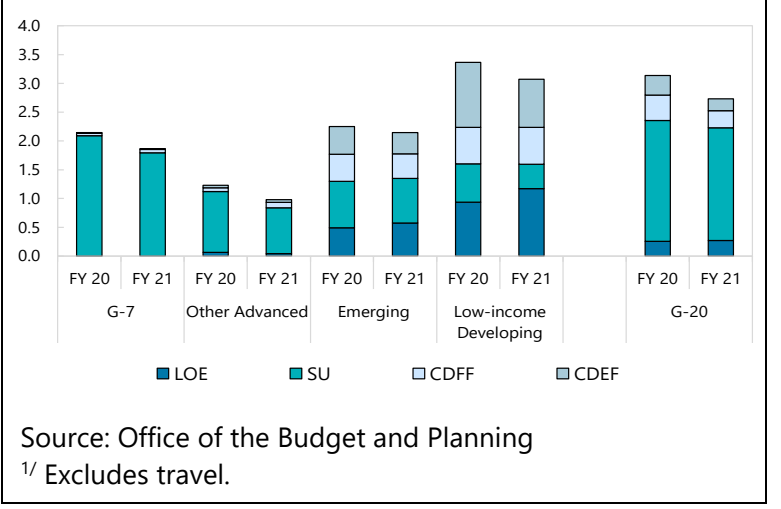


- $\quad$ Fragile states. The Fund has helped many FCS achieve macroeconomic stabilization and build progressively stronger institutions through $C D$ and lending. Surveillance and $C D$ are important for countries without Fund lending. The Fund has also played a central role in the international response to the COVID-19 pandemic in FCS, through initiatives aimed at improving debt sustainability. Given the importance of externally-financed CD in FCS, spending in the 42 FCS in FY21 declined by 9 percent to $\$ 104$ million (from $\$ 114$ million in FY20), and by 3 percent to $\$ 76$ million excluding externally financed CD. Some 46 percent of FY21 spending was delivered through CD. Area Departments channeled about half of the resources to fragile states-mostly in AFR, APD, and MCD-in support of country operations, particularly engagement related to program work.

8. Multilateral Surveillance, Analytical and Policy work. Overall spending in these areas increased by 5 percent ( $\$ 13$ million), linked to crisis-related activities.

- $\quad$ Spending on multilateral surveillance increased by 5 percent ( $\$ 6$ million). Fund's flagship publications focused on the crisis and divergent economic recovery, assessments of macro financial risks and spillovers, fiscal responses, identification and assessment of economic and policy spillovers, and longer-term economic and financial challenges related to climate and digitalization. Other areas of work included vulnerability exercise flash updates, including the impact of COVID-19, and strengthening the monitoring of systemic risk.

- $\quad$ Spending on Fund policy work increased by 5 percent ( $\$ 2$ million). This work focused on lending policies to adapt the Poverty Reduction and Growth Trust (PRGT) and General Resource Account (GRA) toolkits for the COVID-19 situation (e.g. conditions for emergency financing, CCRT, new Short-term Liquidity Line). With the crisis exacerbating debt burdens across many countries, important debt policy work was also advanced to reduce debt vulnerabilities, strengthen transparency, and improve the architecture for sovereign debt resolution. Steps were also taken to modernize the Debt Sustainability Framework from Market Access Countries and the IMF lending into Arrears Policies. On surveillance policies, as focused Article IV consultations resumed, policy work advanced on enhancing the Fund's surveillance framework in the context of the Comprehensive

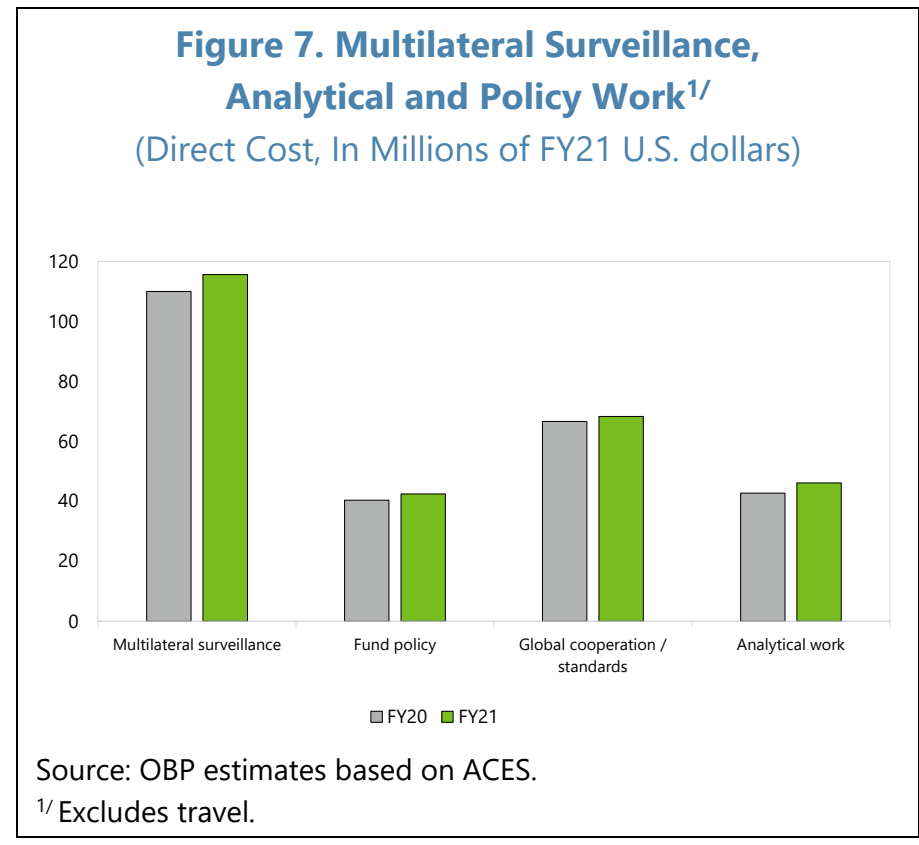
Surveillance and FSAP Reviews. 
- $\quad$ Spending on cooperation on global issues (i.e., participation in various multilateral fora) and standards remained broadly unchanged year-on-year. The Fund continued to support the G-20 to catalyze a coordinated global response to the COVID-19 crisis in the context of the Common Framework and Extension of the G-20 Debt Service Suspension Initiative.

- $\quad$ Spending on Analytic work increased by 8 percent ( $\$ 3$ million) and covered the Fund's tailored policy recommendations and cross-country experience on managing the crisis, including through a country policy tracker and the Database of Country Fiscal Measures in Response to the COVID-19 Pandemic, complemented by a special series of CD-related analytical notes on fiscal, monetary and financial, statistics, and legal policies.

9. IMF Governance and Fund Finances. Spending on these categories declined by 5 percent (\$6 million), reflecting lower spending on governance and which more than offset a $\$ 3$ million increase in spending associated to Fund finances. On governance, the work on the 16th General Review of Quotas continued, while work on an SDR allocation to supplement existing reserves, bolster global financial resilience, and provide timely assistance to Low-Income Countries and Emerging Markets was initiated.

10. Internal support. Overall spending on internal support rose by 2 percent ( $\$ 5$ million) yearon-year. The work in a remote environment triggered by the pandemic in late FY20 required emergency HR measures, swift enhancements to the IT platforms and essential equipment for staff to mitigate the risks posed to business operations.

- Emergency HR measures included the continued relocation of some field-based staff and family members in early FY21, with a ramp-up in recruitment efforts related to crisis hiring.

- A broad range of safety and health protocols were implemented to protect staff (e.g., enhanced cleaning protocols and alterations for touchless entrance/exits, temperature scanning).

- A ramp-up in implementation of $\mathrm{HR}$ and $\mathrm{CD}$-related modernization contributed to this increase.

- Unprecedented broadcast, video and language services support ensured a smooth process for virtual missions and the virtual Spring and Annual Meetings. These measures reinforced the operational continuity framework in the crisis without much increase in service costs.

\section{B. Spending by Department}

11. Changes: Crisis impact is evident at a departmental level (Figures 8-9).

- $\quad$ Area Departments: ADs saw a shift in spending (excluding travel) from surveillance to lending-related activities (AFR, APD, WHD) and a jump in regional analytical work (APD, $M C D)$. 
- $\quad$ Non-CD functional departments: A few departments (SPR, FIN) also saw an increase in lending output due to the review of high volume of crisis lending and the temporary suspension in surveillance activities in ADs.

- CD departments:

Lower overall spending (excluding travel) mainly reflects the sharp decline in externally financed activities (FAD, ICD, MCM, STA). Excluding externally funded $C D$, output was stable or increased relative to FY20 in most CD departments. $A$ decline in Fundfinanced $C D$ in some cases also reflects a shift toward analytical products (including practice notes) and tool development (including to support virtual $C D$ delivery). FAD, MCM, LEG and STA also increased multilateral surveillance and

Figure 8. Change in Outputs by Department, FY21 vs FY201/ (Millions of FY21 U.S. Dollars)

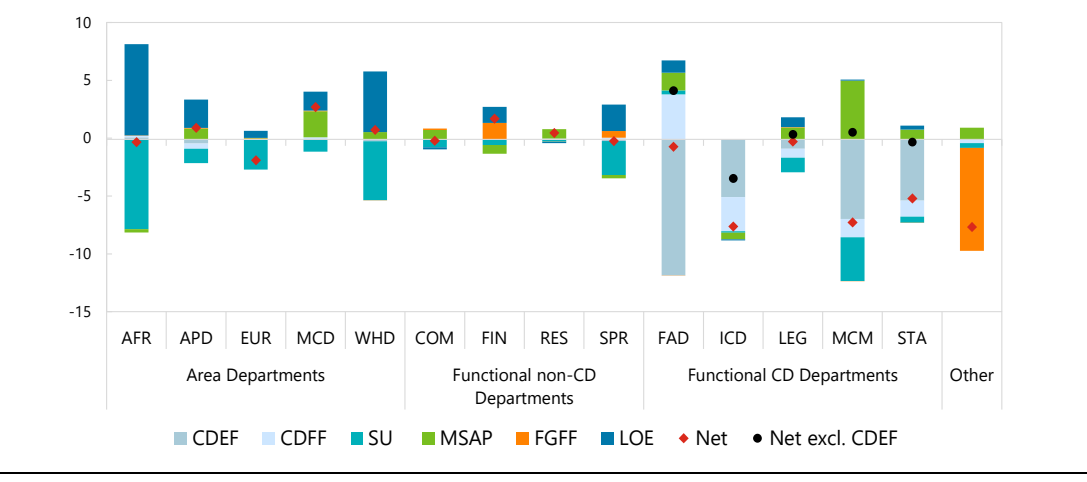

Figure 9. Spending by Department Type and Outputs, FY211/ (Millions of FY21 U.S. Dollars)

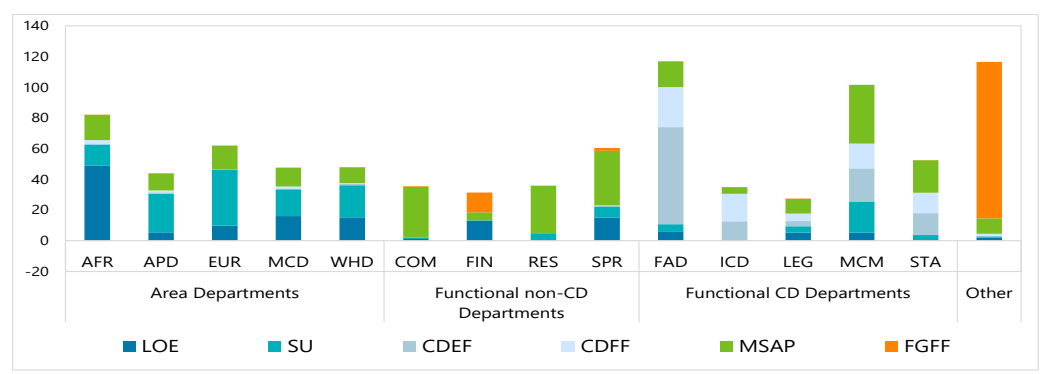

Source: OBP estimates.

${ }^{1 /}$ Excludes travel analytic and policy-related work. Following the outbreak of the COVID-19 crisis, STA and ICD loaned significant staff resources to ADs, FIN, and SPR to provide temporary support for crisis-related work.

- $\quad$ Support and other: Lower overall spending (excluding travel) mainly reflects the sharp decline in Fund governance and membership (CSF, OED, SEC) amid delays in non-crisis related governance activities.

\section{Spending by Priority Topics}

12. Priority Spending (Figure 10). The FY21 budget continued to support incremental increase in resources to advance Fund work on key priority topics. 
- Financial surveillance. Estimated spending reached around \$83 million ( $\$ 77$ million in FY20). With the pandemic, the focus was in assessments of financial sector vulnerabilities; transmission of financial distress across sectors; and policies to support financial stability and minimize the impact of rising defaults. MCM accounts for 57 percent of this spending, through direct area department support, multilateral surveillance and policy work.

- Debt. Policy and analytical work is estimated at $\$ 43$ million. Focus was on supporting members to reduce debt vulnerabilities, increase debt transparency and strengthen debt management capacity, which has gained increasing importance after the crisis. Some efforts on this area took place in the context of the CCRT and G-20 Debt Service Suspension Initiative (DDSI), and mainly by $A D$ and functional $C D$ departments. No comparator data in FY20 is available.

- Inclusion/gender. Spending in this topic, is estimated at $\$ 36$ million. The focus was on analysis of macro-critical inclusion and gender issues; and assessments of inclusion gaps and redistributive policies triggered by the crisis. The work was carried out mainly by area departments and functional non-CD departments (RES). No comparator data in FY20 is available.

- Monetary policy. Spending on work related to monetary policy is estimated at $\$ 35$ million, allowing continued work on the IPF, work on monetary policy frameworks, and review of the Fund's institutional view on capital flows, albeit with some delays due to the pandemic. The spending is evenly split across ADs, functional CD departments, and functional non-CD departments. No comparator data in FY20 is available.

- Climate change. Spending on climate work has ramped up significantly and is estimated at $\$ 28$ million in FY21 (\$16 million in FY20). In ADs, climate work focused on countries with the largest needs in mitigation and adaptation. In functional departments, spending contributed to the work on mitigation and adaptation and to increase expertise to support country work (e.g., Climate Change Policy Assessments-CCPA, and Climate Risk Analysis in FSAPs). 
- Governance/corruption. Spending in this area is estimated at \$23.9 million in FY21. With the pandemic, the focus of this work was on addressing governance and corruption vulnerabilities in member countries to ensure appropriate accountability and transparency of COVID-19 financial resources. Spending concentrated mainly in ADs, with support from functional departments (SPR, LEG, FAD, and FIN) through direct CD and review work. While no comparator data for FY20 is available, departments report a drop in the work on this area linked to the reduced work on Article IV Consultations.

- Digital money. Spending on digital money is estimated at $\$ 4$ million ( $\$ 6$ million in FY20) and work included macro-financial implications of cross-border use of digital currencies; and initial considerations for developing an analytical framework for central bank digital currencies. Most of it centered on analytic and policy work in functional departments (MCM, LEG, SPR)

\section{SECTION III. SPENDING BY INPUTS}

\section{A. By Major Budget Category}

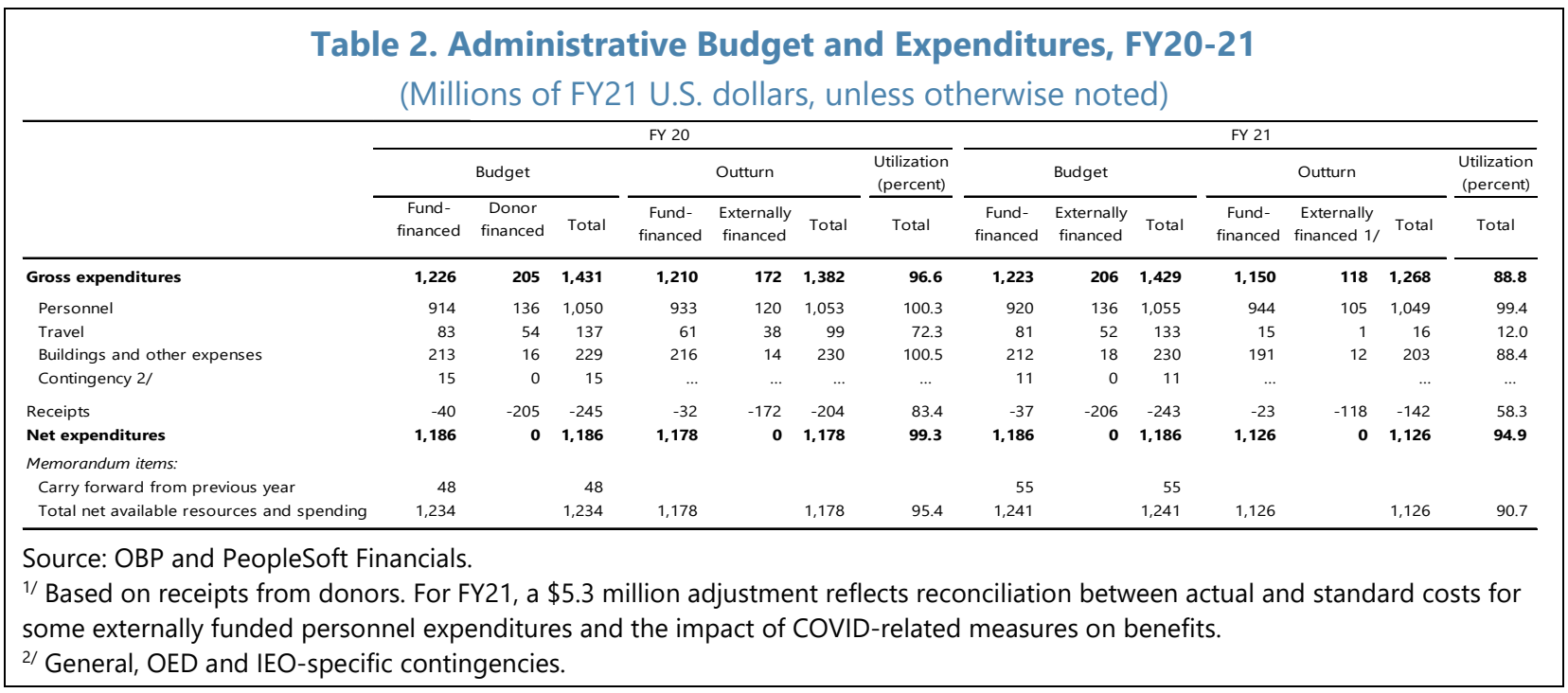

13. Personnel. Total personnel spending was $\$ 1,049$ million, some $\$ 6$ million below the April structural budget. Fund-financed personnel spending exceeded the original structural budget by about $\$ 24$ million, reflecting reallocation of resources toward staffing during the year. Spending on externally financed personnel was about $\$ 30$ million below budget, mainly reflecting lower-thanprojected spending on short-term experts. Personnel levels mirrored this outcome (Figure 11). Despite an overall 1.8 percent increase in FTEs relative to FY20, total personnel spending in real terms declined by 0.8 percent. The $\$ 4$ million decline in personnel spending from FY20 to FY21 owes to a $\$ 15$ million reduction in externally financed personnel spending, partially offset by a $\$ 11$ million increase in Fund-financed personnel spending. Between FY20-21, there was a decline in spending on expatriate benefits for evacuated field-based personnel. The cost of evacuations is recorded under security-related spending. 


\section{Figure 11. Trends in Personnel Spending}

Fund-financed regular staff increased by 44 positions in FY21 while externally financed personnel, mostly experts and contractual, declined by 24 FTE-equivalent positions, driven by lower use of short-term experts.

Personnel, FTEs, FY20-21

\begin{tabular}{lrrrr}
\hline & FY 19 & FY 20 & FY 21 & $\begin{array}{c}\text { Difference } \\
\text { FY 20-21 }\end{array}$ \\
\hline Total & 3,899 & 3,912 & 3,981 & 69 \\
Fund-financed & 3,453 & 3,485 & 3,578 & 94 \\
Regular and term & 2,865 & 2,886 & 2,928 & 42 \\
Expert and contractual & 588 & 599 & 651 & 52 \\
Externally financed & 446 & 427 & 402 & $(24)$ \\
Regular and term & 93 & 96 & 94 & $(3)$ \\
Expert and contractual & 353 & 330 & 309 & $(21)$ \\
\hline
\end{tabular}

The level of externally financed staff and contractuals declined in FY21 due to interruptions to in-person CD delivery during the crisis.

\section{Staffing Levels ${ }^{1 /}$ \\ (In percent change)}

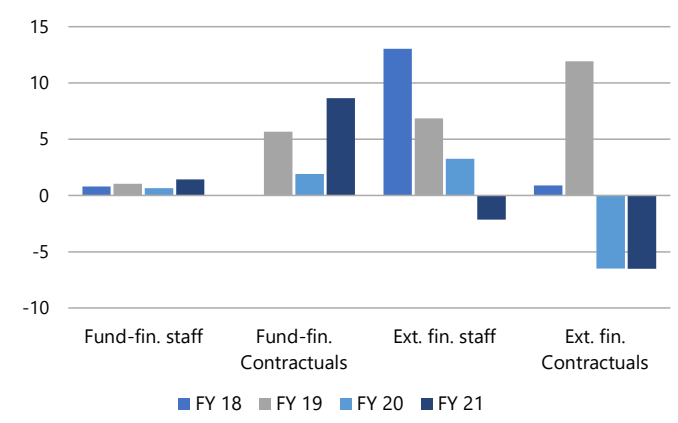

1/ Contractuals refers to Fund-financed and externally financed experts (including short-term), contractuals, visiting scholars, secretarial support and other.
The staff vacancy rate increased to 3.8 percent. This increase reflects lags to hiring from delays in the internal job market and challenges to the remote hiring process.

\section{Vacancy Rate by Department Type,} FY20-21 (Percent, end year)

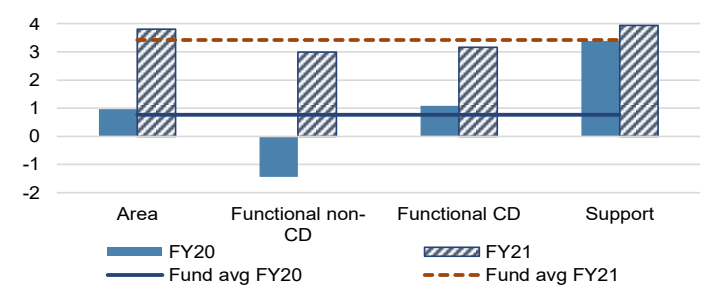

Total personnel spending in FY21 prices declined slightly, while the share of salaries and benefits relative to total outturn increased given larger declines in other categories of spending.

Personnel Expenditures, FY08-21/

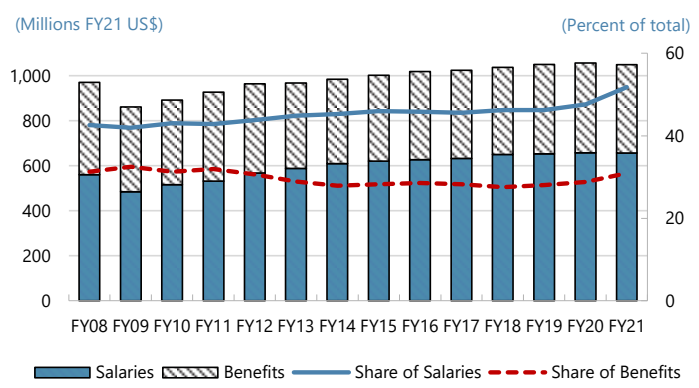

1/ Spending represents both Fund- and externally financed personnel costs. 
14. Crisis hiring and vacancies. During FY21, 128 temporary crisis staff positions were allocated to meet crisis demands, including many at mid-year, with hiring continuing into FY22. This contributed to an overall vacancy rate (including both structural and temporary positions) of about 3.8 percent (120 vacancies) compared to 0.8 percent (23 vacancies) in FY20 and an average of 1.1 percent over the previous five years. The underutilization of crisis positions-allocated in November 2020 - was expected, given the time needed for ramp up recruitment amid challenges related to remote hiring and new HR processes. The jump in vacancy rates mirror that following the Global Financial Crisis (Figure 12). HRD has put in place some measures to help address hiring challenges, including by establishing a centralized recruitment framework for external hiring through the midcareer pipeline, and accelerating the pipeline's replenishment.

15. Travel. As noted, Fund travel came to a near stand-still in FY21, with most of these resources repurposed to crisis related needs.

- $\quad$ Missions fell from 6,693 mission in FY20 to 16 missions in FY21 (Table 3). Of these, six were AD led missions related to program negotiations and consultations with authorities; three were led by SPR in support to the G20 processes; and the remainder were regional travel within the APD region.

- The largest share of total travel expenditures related to evacuation costs of field staff ( $\$ 7.9$ million), reflecting pandemic response. Settlement/relocation travel (\$6.3 million) declined by 27 percent, with fewer Res Rep installations.

\begin{tabular}{|c|c|c|c|}
\hline \multicolumn{4}{|c|}{$\begin{array}{c}\text { Table 3. Travel, FY19-21 } \\
\text { (Number of Missions) }\end{array}$} \\
\hline & FY 19 & FY 20 & FY 21 \\
\hline By region & 7,858 & 6,693 & 16 \\
\hline AFR & 1,970 & 1,673 & 0 \\
\hline APD & 1,615 & 1,257 & 9 \\
\hline EUR & 1,645 & 1,517 & 2 \\
\hline MCD & 675 & 611 & 1 \\
\hline WHD & 1,953 & 1,635 & 4 \\
\hline By department type & 7,858 & 6,693 & 16 \\
\hline Area & 1,445 & 1,180 & 13 \\
\hline CD Functional & 4,979 & 4,207 & 0 \\
\hline Non-CD Functional & 788 & 719 & 3 \\
\hline Support and Governance & 646 & 587 & 0 \\
\hline Funding source & 7,858 & 6,693 & 16 \\
\hline Fund-financed & 4062 & 3513 & 10 \\
\hline Externally financed & 3861 & 3180 & 6 \\
\hline \multicolumn{4}{|c|}{$\begin{array}{l}\text { Source: OBP. } \\
\text { Missions relate to a single beneficiary and may include more } \\
\text { than one IMF mission participant. } \\
\text { FY21 numbers exclude Virtual missions. }\end{array}$} \\
\hline
\end{tabular}


16. Buildings and other services. Spending on building operations and other services was 10 percent below budget (Figure 12). Underspend was driven by the extended remote working environment and the low building occupancy that reduced the spending on utilities, goods and services, maintenance, and the Annual/Spring Meetings. Fund-wide IT spending was also below budget due to crisis-related delays in some activities, deferral of non-priority work, and a change in vendor services. These savings more than offset the higher spending to support staff's IT equipment for remote working.

17. Security-related spending. Security spending rose by $\$ 3$ million relative to $F Y 20$ to $\$ 42$ million, mainly reflecting field security due to evacuations, in-country security needs in high risk locations, and heightened international security surveillance (Figure 13). Business Continuity also saw a marginal increase with the impact of the pandemic somewhat offset by reduced security needs at $\mathrm{HQ}$ (e.g., virtual Annual and Spring Meetings) and lower IT security costs due to temporary reductions in licensing costs.

18. Receipts (Table 4). Overall FY21 receipts were $\$ 142$ million, some 40 percent below budget and about 30 percent lower than FY20 receipts. This mainly reflects the fall in receipts from externally financed CD from travel restrictions (and related impact on hiring short-term experts) and absorption constraints in some countries. The fall in externally financed $C D$ in turn reduced income in the TFMF, as noted. The remote work environment also affected revenue from the HQ2 lease, while travel restrictions reduced Concordia revenues.

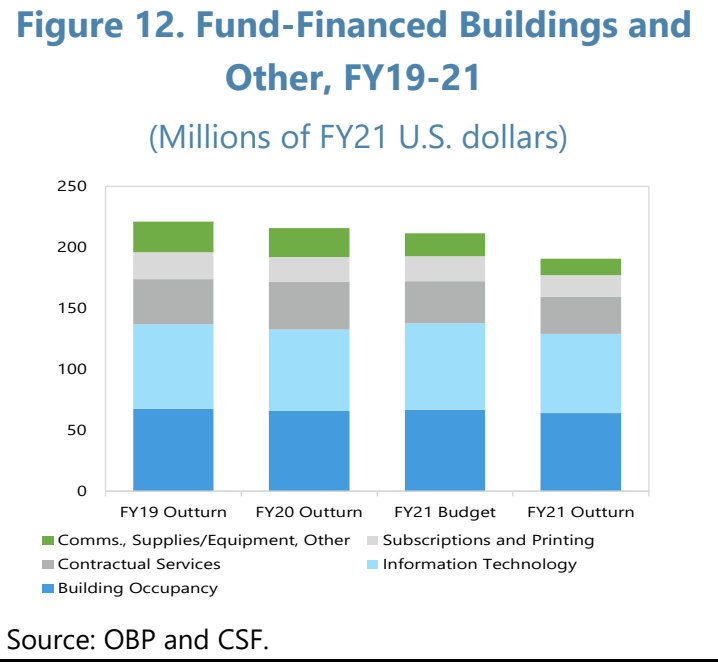

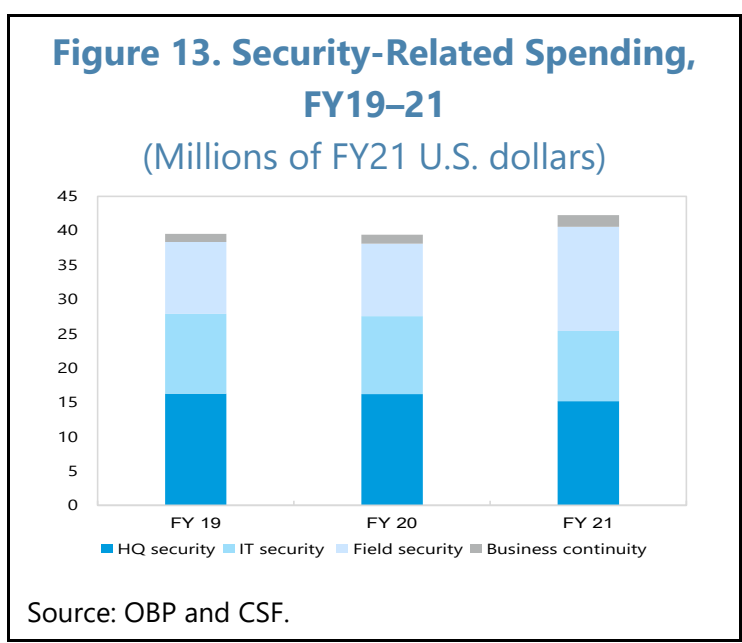

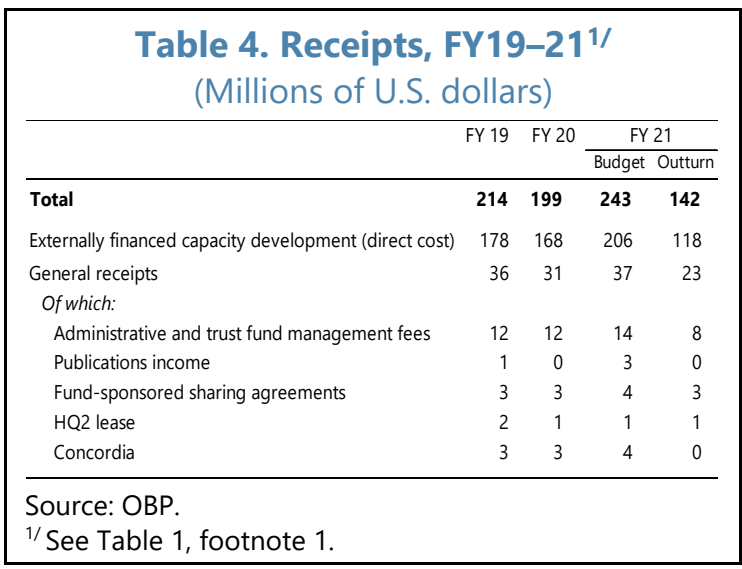


19. Use of carry forward. Following the approval by the Board of the increased general carry forward limit from 3 to 5 percent with the FY21-23 Medium-Term Budget, \$44.4 million in carry forward resources were available. About three-quarters ( $\$ 37.5$ million) had been distributed upfront to department to meet transitional needs. The remainder was allocated over the course of the year to meet crisis needs.

\section{SECTION IV. CAPITAL SPENDING}

\section{Capital spending.}

Approximately $\$ 186$ million capital funds appropriated between FY19-21 were available in FY21, split between ITrelated ( $\$ 82$ million) and facilitiesrelated (\$104 million) resources, with the latter including HQ1 Renewal-related (\$16 million) investments (Table 5). FY21 spending totaled $\$ 77$ million, a reduction of $\$ 30$ million from last year. Approximately $\$ 109$ million in remaining appropriated funds will carry over to FY22.

\section{IT Capital Expenditure.}

Utilization of available funds was 61 percent (broadly in line with FY20). IT modernization projects have continued despite the crisis. A modest repurposing of funds allowed for enhancement of security of the business continuity center to support the heavy remote work environment. Within overall IT capital expenditure of $\$ 50$ million, 72 percent (\$36 million) supported the implementation of the transformational modernization projects (Figure 14).

- The 1HR program ( $\$ 17$ million in FY21) represented the largest share of FY21 spending on transformational IT, including $\$ 1.8$ million of the total additional program budget of

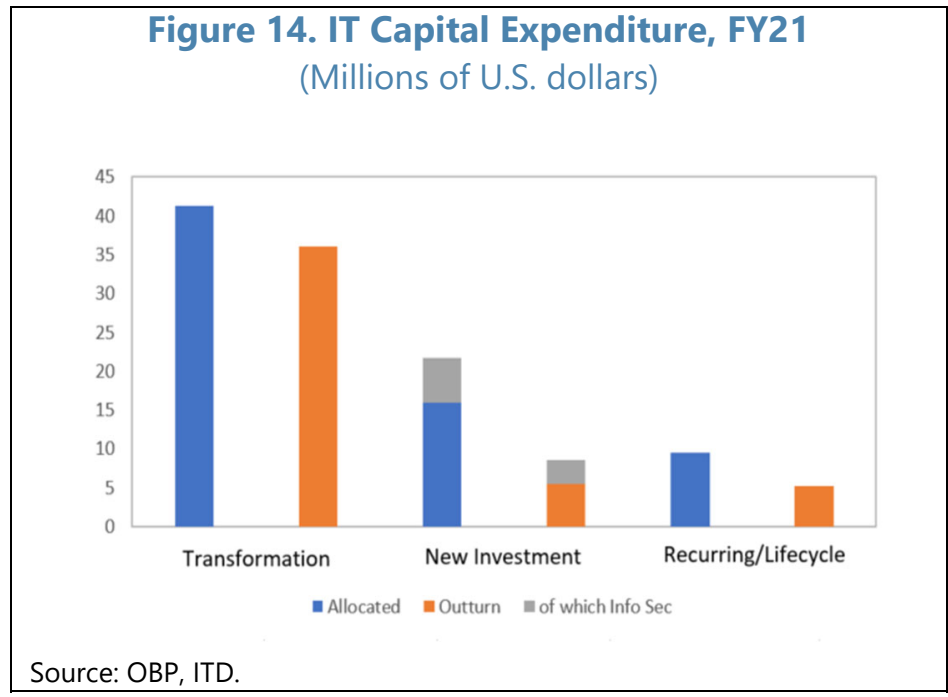
$\$ 23$ million presented to the Board in April 2021. The program saw the initial rollout of two of four releases, including the bulk of general staff-facing HR service interfaces with the launch of MyWorkday and MyHR.
Table 5. Capital Expenditures, FY20-211/

(Millions of U.S. dollars, unless otherwise indicated)

\begin{tabular}{lrrrrrr}
\hline & $\begin{array}{c}\text { FY 20 } \\
\text { Spending }\end{array}$ & $\begin{array}{c}\text { Approved in } \\
\text { FY21 }\end{array}$ & $\begin{array}{c}\text { Total } \\
\text { Funds } \\
\text { Available in } \\
\text { FY 21 }\end{array}$ & $\begin{array}{c}\text { FY 21 } \\
\text { Outturn }\end{array}$ & $\begin{array}{c}\text { FY 21 } \\
\text { Utilization } \\
\text { (percent) }\end{array}$ & $\begin{array}{c}\text { Carry Over } \\
\text { into FY 22 2/ }\end{array}$ \\
Total & $\mathbf{1 0 7}$ & $\mathbf{9 9}$ & $\mathbf{1 8 6}$ & $\mathbf{7 7}$ & $\mathbf{4 1}$ & $\mathbf{1 0 7}$ \\
Facilities & $\mathbf{6 5}$ & $\mathbf{4 2}$ & $\mathbf{1 0 4}$ & $\mathbf{2 7}$ & $\mathbf{2 6}$ & $\mathbf{7 4}$ \\
$\quad$ Building & 42 & 42 & 88 & 26 & 29 & 60 \\
$\quad$ HQ1 Renewal & 23 & 0 & 16 & 2 & 9 & 15 \\
IT & $\mathbf{4 2}$ & $\mathbf{5 6}$ & $\mathbf{8 2}$ & $\mathbf{5 0}$ & $\mathbf{6 0}$ & $\mathbf{3 3}$ \\
\hline
\end{tabular}

Sources: OBP, Corporate Services and Facilities, and Information Technology Departments. Numbers might not add up due to rounding. 1/ Approved capital funding is available for three consecutive years, except for HQ1 Renewal which is available until April 2025.

2/ Net of FY 21 lapsed funds. 
- $\quad$ The CDMAP project (\$7 million) completed two releases between August 2020 and April 2021, and expects to remain on budget despite a 2-month extension in the completion timeline for the final release to October 2021. The FY22-24 Prioritization and Medium-Term Work Planning Process (previously the Resource Allocation Plan) was undertaken using the new system.

- Other transformational projects (\$6.8 million), comprising Knowledge Management, iDW and iData also progressed during year. Knowledge Management spending $(\$ 4.6 \mathrm{~m})$ was largely as per expectations and focused on the development of the new document management system, which is expected to be deployed in Q3 FY23. During FY21, the iDW project ( $\$ 0.9$ million) was reconfigured and the implementation of collaboration tools (MS Teams) was prioritized. Spending on the iData project (\$1.3 million) was lower than expected due to delays in finalizing the development environment to comply with the Fund's strengthened security posture. Work also began on the implementation of pre-requisite projects such as Identity and Access Management (IAM), and the Corporate Data Warehouse $(C D W)$, for which expenditures ( $\$ 4.5$ million) were broadly aligned with budget allocations.

- $\quad$ Other IT Investments. New investments spending amounted to $\$ 8.5$ million (compared to $\$ 5.2$ million last year). A large share ( $\$ 3$ million) related to Information Security enhancements, including for projects relating to Security Event and Incident Management (ArcSight) and the Business Continuity Center Cloud Migration. Spending on lifecycle replacements amounted to $\$ 5.2$ million, which was broadly in line with FY20 spending ( $\$ 4.9$ million). The largest projects within this category were a PC refresh ( $\$ 1.5$ million) and server replacements ( $\$ 1.3$ million).

22. Facilities Capital Spending. Utilization of available funds was 30 percent (47 percent in FY20). Spending was lower at $\$ 26$ million ( $\$ 42$ million in FY20), driven largely by postponement of several campus-based projects in light of the crisis and a shift in focus from HQ1 renewal to timely updates and modernization of facilities (Figure 15). Other projects, such as furniture replacements, were also postponed due to supply shortages and changing needs stemming from the hybrid work model. Some projects that benefitted from low building occupancy were accelerated,

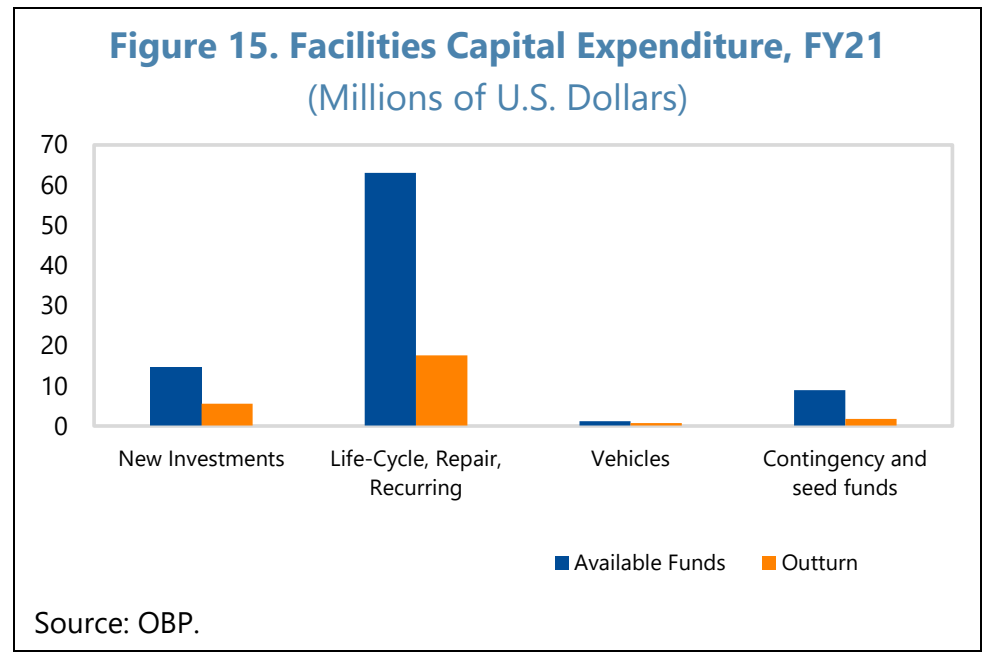
providing a partial offset. This includes replacement of building systems nearing end of life and restroom renovations. Response to the pandemic was also prioritized, including installation of touchless door openers and ultraviolet lighting for air purification. 


\section{Annex I. Technical Annex-Concept and Methodologies}

\section{Budget Concepts}

Financial year (t): May 1(t-1) to April 30(t)

E.g., FY21 = May 1, 2020 to April 30, 2021

\section{Administrative budget:}

Gross (total spending envelope)

- (minus)

Receipts (donor funding + revenue)

$=$

Net (spending that needs funding)

$\underline{\text { Total Available Resources }}=$ Net + Carry Forward

\section{Carry forward:}

The right to spend budget allocations beyond the period for which budgetary authority is normally granted (12 months). Carry forward (CF) limits are set for the IEO, OED, and at the general level. The general CF limit has varied over time. With the FY21-23 Budget, the Board approved a temporary increase in the general CF limit from 3 to 5 percent in response to COVID crisis. The CF is the minimum of the underspend in the current year or CF limit of the current year's approved net administrative budget. Specifically:

\section{$\mathbf{C F}_{\mathbf{t}}=\min \left(\mathbf{U}_{\mathbf{t}}, x \mathbf{B}_{\mathbf{t}}\right)$}

Where:

$\mathrm{U}_{\mathrm{t}}=$ underspend in current $\mathrm{FY}\left(\mathrm{B}_{\mathrm{t}}+\mathrm{CF}_{\mathrm{t}-1}-\mathrm{E}_{\mathrm{t}}\right)$

$B_{t}=$ net administrative budget in current $F Y$

$\mathrm{CF}_{\mathrm{t}-1}=$ carry forward from previous $\mathrm{FY}$

$E_{t}=$ net expenditures in current $F Y$

$x=$ ratio limit of $\mathrm{CF}$

\section{Global external deflator:}

Starting in FY21, the global external deflator is the U.S. CPI projection as published in the most recent WEO which is the January WEO Update (Annex II of the FY21-23 Medium-Term Budget for the revision of the global external deflator).

\section{Capital budget:}

Used to finance investments in information technology and building improvements and repairs. Given the long-term nature of these projects, capital budgets are available for a period of three years, after which unspent appropriations lapse.

A project is included in the capital budget if it is for:

- acquisition of building or IT equipment

- construction, major renovation, or repairs

- $\quad$ major IT-intensive business process

redesign or development

- $\quad$ major infrastructure projects 


\section{Annex II. Capacity Development ${ }^{1}$}

1. This annex provides additional information on CD activities. It reports on overall spending on $C D$ activities, $C D$ distribution, training participation, and sources of external financing.

\section{A. Overall Spending on CD Activities}

2. Total Activity. Spending on CD fell by $\$ 54$ million or around 18 percent year-on-year, bringing the share of $C D$ in the Fund's total output down to around a quarter from about 30 percent pre-crisis (Annex Figure 2.1). This largely reflects the travel moratorium, with total CD activity excluding travel falling six percent year-on-year. The remaining decline results mainly from reduced use of short-term experts in light of travel constraints and crisis-related absorptive capacity issues (Annex Figure 2.2.). Staff and long-term experts largely maintained their level of CD activity by shifting to virtual delivery, online learning and global workshops, with additional work related to development of general guidance on crisis-related issues.

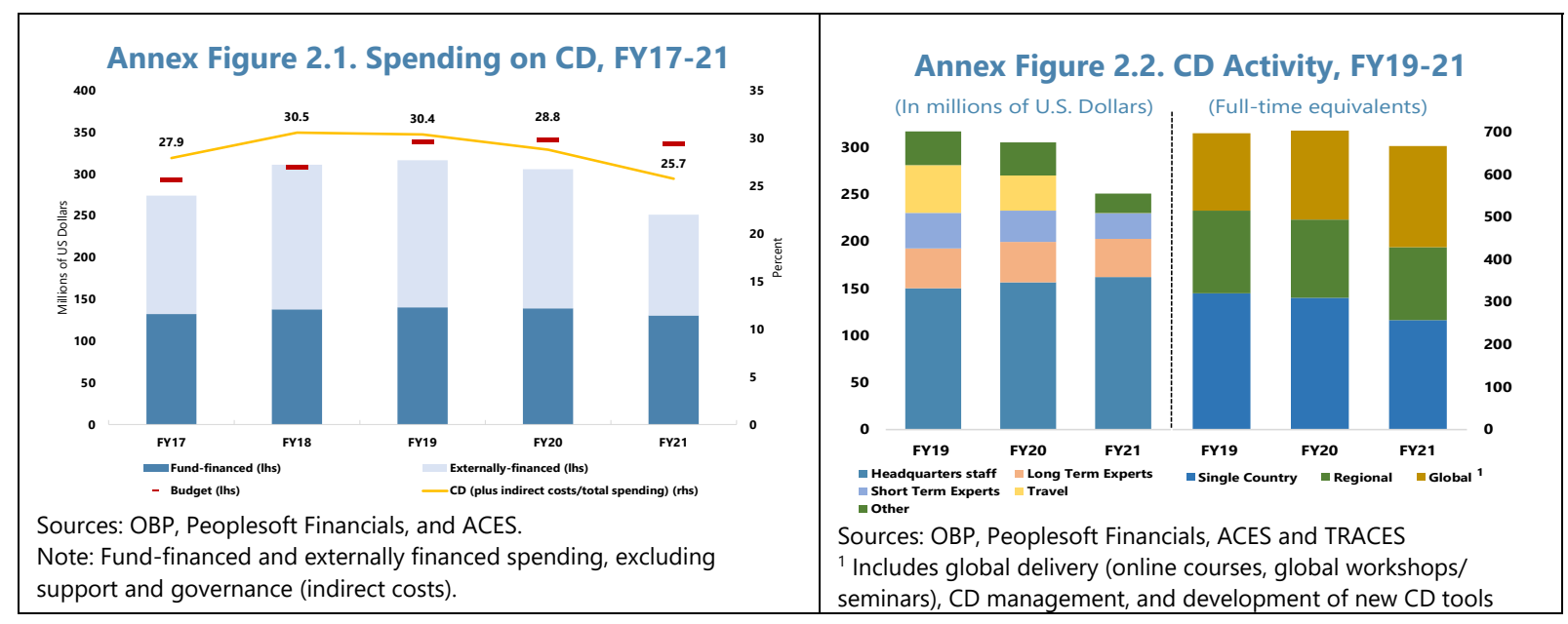

3. Utilization. Fund-financed spending was 91 percent of the budget, reflecting the flexibility of this funding and rapid reallocation to address crisis-related CD need, and the fact that these Funds cover a substantial share of CD management and administration activities. The crisis impact was larger on the externally financed CD budget, with a greater share of travel and expert spending that could not be quickly reprogrammed (Annex Figure 2.3). Externally financed receipts were just under 60 percent of the original FY21 budget at $\$ 118$ million.

\section{Impact of Externally financed CD shortfalls on Fund-financed budget. Given strong} virtual delivery, charge backs on externally funded CD were higher-than-projected at the onset of the crisis, at 94 percent of budget. Nevertheless, the shortfall ( $\$ 2.7$ million) and the impact of lowerthan-budgeted fund management fees that are linked to overall dollar delivery ( $\$ 6.1$ million) led to an overall impact on the net administrative budget of $\$ 8.8$ million.

\footnotetext{
1 Prepared by Oana Croitoru, Carolina Dyer-Lock, Natan Epstein, Felicia Ge, Herbert Lui, Valeria Mensah, Yan Sun, André Vieira de Carvalho, and Biwen Zhou (all ICD).
} 


\section{B. CD Distribution}

5. Prioritization. The CD prioritization framework, based on country demand and the Fund's overall strategic priorities, guides the allocation of resources across regions and topic areas. ${ }^{2}$ The framework provides flexibility for the Fund to respond to short-term CD needs, which has been evident in the response to the COVID-19 crisis over the past fiscal year. This includes use of Fundfinanced funding to cover CD in countries/regions with less access to external funding, reorientating externally funded projects to immediate member needs, or providing "on demand" advice under more flexible trust funds).

- By region. Regional distribution shifted slightly towards regions that typically receive less CD (Annex Table 2.1, Annex Figure 2.3). AFR continued to receive the largest share of direct delivery (around 36 percent in FY21), followed by APD. Nevertheless, these shares decreased 1.3 and 2.8 percentage points, respectively, in FY21. The larger drop in APD can be explained by the lower activity in Myanmar and in the region's training centers. Other regions experienced an increase in share, with activities benefitting multiple regions growing significantly more than originally planned due to delivery of more online courses and workshops during the pandemic.

- By income group. Similarly, FY21 saw an increase in the share of CD received by Advanced Economies, not traditional recipients, although this share remained under 5 percent.

2 IMF Policies and Practices on Capacity Development, October 2019. 


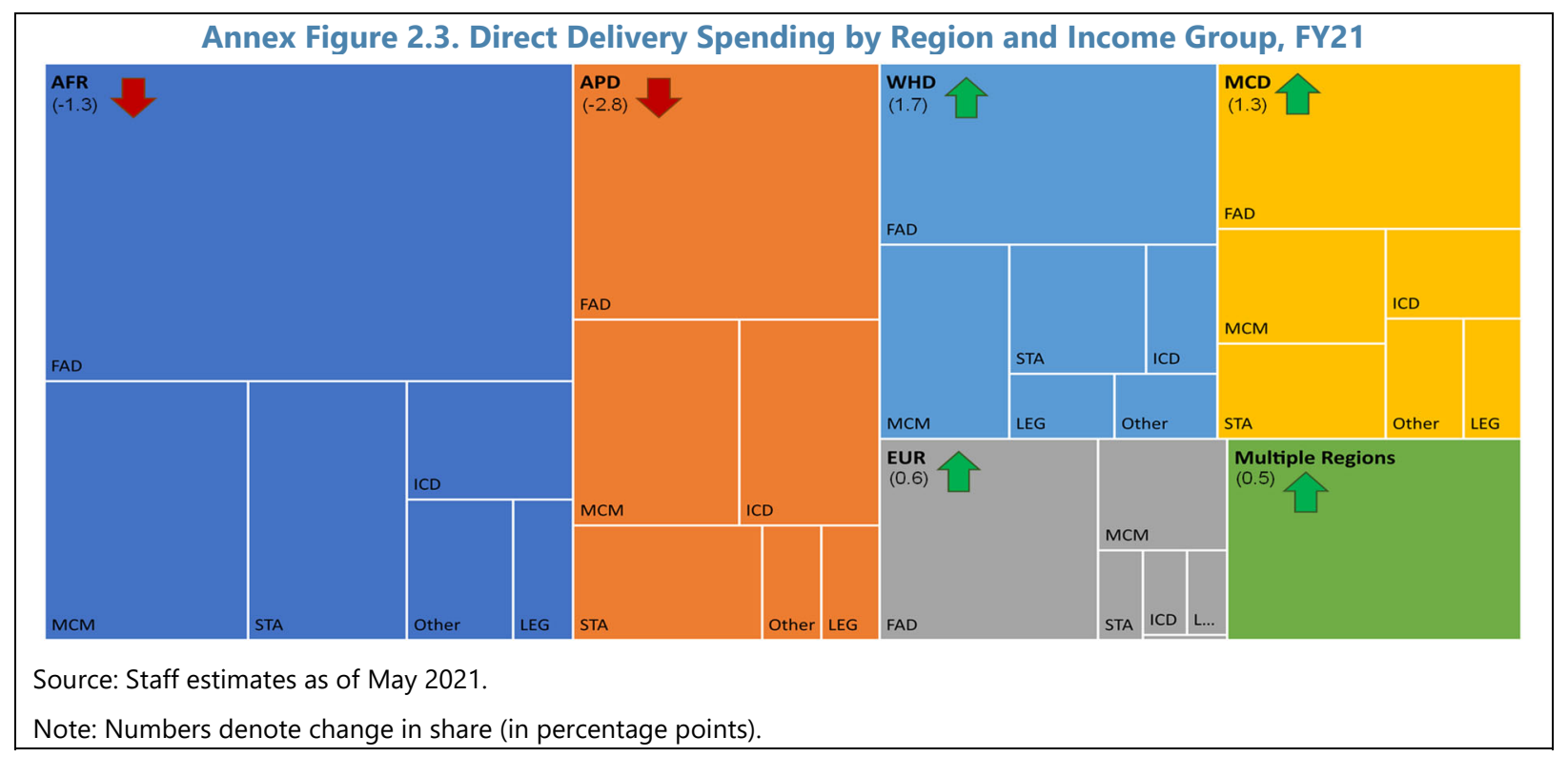

\begin{tabular}{|c|c|c|c|c|c|}
\hline \multicolumn{6}{|c|}{$\begin{array}{l}\text { Annex Table 2.2. Direct Delivery on Core Workstreams, FY20-21 } \\
\text { (In percent, unless otherwise indicated) }\end{array}$} \\
\hline \multirow[b]{4}{*}{ Total Direct Delivery on Core Workstreams } & \multirow{4}{*}{$\begin{array}{c}\text { FY } 20 \text { Outturn } \\
\text { Share } \\
{[1]} \\
\mathbf{1 0 0 . 0}\end{array}$} & \multirow{4}{*}{$\begin{array}{c}\begin{array}{c}\text { FY } 21 \text { Budget } \\
\text { Share }\end{array} \\
{[2]} \\
\mathbf{1 0 0 . 0}\end{array}$} & \multirow{4}{*}{$\begin{array}{c}\text { FY } 21 \text { Outturn } \\
\text { Share } \\
{[3]} \\
\mathbf{1 0 0 . 0}\end{array}$} & \multicolumn{2}{|c|}{ FY 21 change in share (p.p.) } \\
\hline & & & & To FY20 & To Budget \\
\hline & & & & {$[3]-[1]$} & {$[3]-[2]$} \\
\hline & & & & & \\
\hline Public Finances & 44.8 & 45.7 & 47.8 & 3.0 & 2.1 \\
\hline Domestic Revenue Mobilization & 24.4 & 24.5 & 22.6 & -1.8 & -1.9 \\
\hline Macro-Fiscal Policies & 0.7 & 1.3 & 2.9 & 2.2 & 1.6 \\
\hline Public Financial Management and Expenditure Policy & 19.7 & 19.9 & 22.3 & 2.6 & 2.4 \\
\hline Monetary and Financial Systems & 18.7 & 20.1 & 17.2 & -1.5 & -2.9 \\
\hline Central Bank Operations and Market Development & 5.2 & 6.3 & 4.4 & -0.8 & -1.9 \\
\hline Financial Sector Stability & 13.5 & 13.8 & 12.7 & -0.7 & -1.0 \\
\hline Macroeconomic Frameworks & 16.7 & 14.6 & 17.6 & 0.8 & 2.9 \\
\hline Macroeconomic Statistics & 15.3 & 15.3 & 12.3 & -3.0 & -3.0 \\
\hline Legal Frameworks & 4.0 & 3.7 & 3.9 & -0.1 & 0.2 \\
\hline Other Workstreams & 0.4 & 0.6 & 1.3 & 0.8 & 0.7 \\
\hline
\end{tabular}

6. By workstream. (Annex Table 2.2) Core workstreams continue to make up the bulk of CD delivery. In broad terms, there was a decline in the share of the delivery of monetary and financial systems and macroeconomic statistics workstreams, reflecting crisis-related disruptions. The pattern of delivery by subject area shifted further toward fiscal issues, which now account for 48 percent of total delivery spending, 6 percentage points higher than pre-pandemic (FY19) levels.

7. Growth areas. ${ }^{3}$ The share of delivery to topical growth areas remained largely unchanged from FY20 (Annex Table 2.3). The share of spending on debt sustainability, debt statistics, and climate change grew albeit from a very low base, reflecting crisis-induced priorities, whereas the share of $C D$ in the anti-corruption and tax policy areas, declined.

\footnotetext{
${ }^{3}$ The revised prioritization framework is set out in Box 4 of the FY20-22 Medium-Term Budget.
} 
- Country groups. The share of delivery to country group growth areas grew slightly (Annex Table 2.3). Despite significant technical constraints for virtual $C D$, the share of delivery to fragile and conflictaffected states (FCS), program countries and the CCAM group grew slightly from FY20 levels. The delivery share is programmed to pick-up further, following the adoption of the Fund strategy for engagement with FCS, and benefitting

\begin{tabular}{|c|c|c|c|c|c|}
\hline \multicolumn{6}{|c|}{$\begin{array}{r}\text { Annex Table 2.3. Direct Delivery on Growth Area } \\
\text { (In percent, unless otherwise indicated) }\end{array}$} \\
\hline & FY 20 Outturn & FY 21 Budget & FY 21 Outturn & FY 21 chang & share (p.p.) \\
\hline & Share & Share & Share & To FY20 & To Budget \\
\hline & [1] & [2] & [3] & [3]-[1] & [3]-[2] \\
\hline \multicolumn{6}{|l|}{ Total Direct Delivery } \\
\hline Total Direct Delivery on Topic Growth Areas & 9.3 & 6.1 & 9.3 & & \\
\hline \multicolumn{6}{|l|}{ Topic Growth Areas (identified workstreams within:) } \\
\hline Anti-corruption & 2.0 & 0.5 & 0.6 & -1.4 & 0.1 \\
\hline Debt sustainability and debt statistics & 0.8 & 1.5 & 2.1 & 1.3 & 0.6 \\
\hline Expenditure policy and public investment management & 1.7 & 1.2 & 1.3 & -0.4 & 0.2 \\
\hline Tax policy & 3.8 & 1.7 & 2.5 & -1.3 & 0.8 \\
\hline Fintech and cyber risks & 0.8 & 0.2 & 0.6 & -0.2 & 0.4 \\
\hline Climate change & 0.2 & 1.0 & 2.2 & 2.0 & 1.2 \\
\hline \multicolumn{6}{|l|}{ Country Group Growth Areas } \\
\hline Fragile and conflict-affected states & 27.5 & 26.4 & 27.8 & 0.3 & 1.5 \\
\hline CCAM & 6.6 & 3.1 & 6.6 & 0.0 & 3.6 \\
\hline Memo: Small developing states & 14.5 & 7.5 & 14.3 & -0.1 & 6.8 \\
\hline
\end{tabular}
from the start of CCAMTAC operation.

8. Training Activity. Training's share of overall CD remained relatively stable, with a shift in the share from ICD to other departments (Annex Table 2.4), partly reflecting ICD's strategic shift toward more technical assistance on developing country-specific macroeconomic frameworks. ICD nonetheless remains the largest training provider, followed by STA and FAD. Other departments' share of training activities increased slightly, with the deployment of more online learning, and the delivery of virtual global

\begin{tabular}{|c|c|c|c|c|c|}
\hline \multicolumn{6}{|c|}{$\begin{array}{l}\text { Annex Table 2.4. Direct Delivery on Training by D } \\
\text { FY20-21 } \\
\text { (In percent, unless otherwise indicated) }\end{array}$} \\
\hline & \multirow{2}{*}{$\begin{array}{l}\text { FY } 20 \text { Outturn } \\
\text { Share }\end{array}$} & \multirow{3}{*}{$\begin{array}{l}\text { FY } 21 \text { Budget } \\
\text { Share } \\
\text { [2] }\end{array}$} & \multirow{3}{*}{$\begin{array}{l}\text { FY } 21 \text { Outturn } \\
\text { Share } \\
\text { [3] }\end{array}$} & \multicolumn{2}{|c|}{ FY 21 change in share (p.p.) } \\
\hline & & & & To FY 20 & To Budget \\
\hline & [1] & & & [3]-[1] & [3]-[2] \\
\hline Total Direct Delivery & 100.0 & 100.0 & 100.0 & & \\
\hline Total Direct Delivery on Training & 16.3 & 12.0 & 16.0 & -0.2 & 4.1 \\
\hline Fiscal Affairs Department & 1.2 & 1.0 & 1.6 & 0.4 & 0.6 \\
\hline Ins. for Capacity Development & 11.3 & 7.2 & 9.8 & -1.5 & 2.6 \\
\hline Legal Department & 0.4 & 0.3 & 0.4 & 0.0 & 0.1 \\
\hline Monetary and Capital Markets & 0.6 & 0.7 & 1.7 & 1.1 & 1.0 \\
\hline Statistics Department & 1.8 & 1.6 & 1.3 & -0.5 & -0.3 \\
\hline Other $C D$ delivery departments ${ }^{1 /}$ & 1.0 & 1.1 & 1.2 & 0.2 & 0.0 \\
\hline \multicolumn{6}{|c|}{ Source: Staff estimates as of May 2021.} \\
\hline \multicolumn{6}{|c|}{$\begin{array}{l}{ }^{1} \text { Including area departments and other functional departments reporting CD-related } \\
\text { activities. }\end{array}$} \\
\hline
\end{tabular}
workshops and seminars. AFR received the largest share of training at about 28 percent, followed by APD and WHD (Annex Table 2.5). Online learning has grown rapidly since the onset of the pandemic, with over 6,000 government officials taking training in FY21, and now accounts for about 40 percent of all IMF training. FCS participation remained broadly flat (Annex Figure 2.4), evidencing that communication challenges could not be overcome in FY21. The opening of more online courses for the general public in FY21 also contributed to the stabilization at higher levels of participation. 


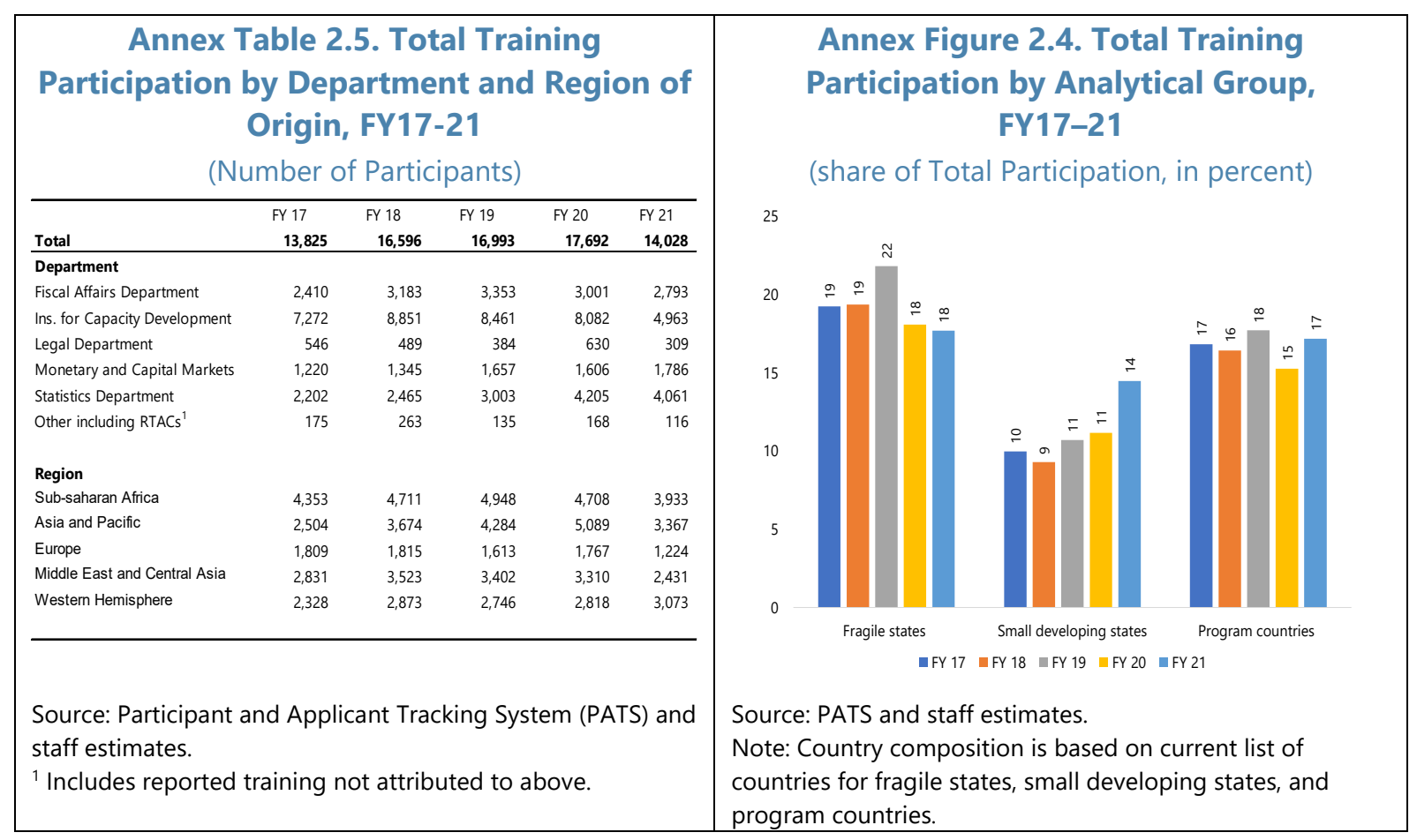

\section{Sources of External Funding}

9. Overview. External partners have continued their substantial support to IMF CD despite their budgetary challenges related to the pandemic (Annex Table 2.6). Fundraising for IMF $C D$ has proved challenging in this setting, although partner support picked up in FY21 relative to FY20 and liquidity balances remain adequate in most $C D$ vehicles. The main pattern of support is consistent with previous years:

- $\quad$ External support is channeled through multi-partner vehicles-regional CD centers, thematic and country funds-and bilateral programs (Annex Table 2.7). In addition, a few countries manage regional training programs, where Fund staff provide training.

\begin{tabular}{|c|c|c|}
\hline \multicolumn{3}{|c|}{$\begin{array}{c}\text { Annex Table 2.6. Partner Contributions, } \\
\text { FY19-211/ }\end{array}$} \\
\hline Donor $\mathrm{C}$ & $\begin{array}{l}\text { Contributions } \\
\text { (Mil. of U.S. dollars }\end{array}$ & $\begin{array}{c}\text { Share } \\
\text { (Percent of total) }\end{array}$ \\
\hline Jopon & (Mil. of U.S. dollars & \\
\hline European Commission & 74 & 12 \\
\hline Germany & 42 & 7 \\
\hline Switzerland & 40 & 7 \\
\hline United Kingdom & 33 & 6 \\
\hline Netherlands & 31 & 5 \\
\hline China & 30 & 5 \\
\hline Canada & 26 & 4 \\
\hline Kuwait & 25 & 4 \\
\hline Norway & 20 & 3 \\
\hline Austria & 15 & 3 \\
\hline $\begin{array}{l}\text { France } \\
\text { Korea }\end{array}$ & $\begin{array}{l}14 \\
14\end{array}$ & $\begin{array}{l}2 \\
2\end{array}$ \\
\hline Australia & 12 & 2 \\
\hline Sweden & 11 & 2 \\
\hline Luxembourg & 10 & 2 \\
\hline New Zealand & 8 & 1 \\
\hline Singapore & 8 & 1 \\
\hline Kazakhstan, Republic Of & $\begin{array}{l}8 \\
5\end{array}$ & 1 \\
\hline Ghana & 5 & 1 \\
\hline Belgium & 4 & 1 \\
\hline Caribbean Development Bank & 4 & 1 \\
\hline Spain & 3 & \\
\hline Sri Lanka & 3 & $\mathrm{o}$ \\
\hline Other donors and institutions & 49 & 8 \\
\hline Total & 600 & 100 \\
\hline $\begin{array}{l}\text { Source: CDIMS Note: Figures } \\
\text { directly by the hosts, which ar } \\
\text { "/ Contributions in FY19-21. }\end{array}$ & $\begin{array}{l}\text { adjusted for RTC } \\
\text { re not reflected ir }\end{array}$ & $\begin{array}{l}\text { costs covered } \\
\text { n IMF accounts. }\end{array}$ \\
\hline
\end{tabular}

- $\quad$ Leading partners for Regional Technical Assistance Centers (RTACs) and thematic funds account for a significant share of the total contribution for respective vehicles (Annex Table 2.8). Still, the share of recipient members' contributions to RTACs has been steady at close to 30 percent reflecting strong member ownership. This helps ensure the financial sustainability of these regional centers. Some RTACs, nevertheless, face potential funding challenges. 


\begin{tabular}{|c|c|c|c|c|c|c|c|}
\hline \multicolumn{3}{|c|}{$\begin{array}{c}\text { Annex Table 2.7. Capacity Development } \\
\text { Vehicles: Top 10 Partner Contributions, } \\
\text { FY19-21 }\end{array}$} & \multicolumn{5}{|c|}{$\begin{array}{c}\text { Annex Table 2.8. RTACs and TTFs: Partner } \\
\text { and Member Contributions to Current } \\
\text { Phase }^{1 /}\end{array}$} \\
\hline & & & & \multicolumn{2}{|c|}{ RTACs } & \multicolumn{2}{|c|}{ TTFs } \\
\hline Multi-partner & $\begin{array}{c}\text { dollars) } \\
276\end{array}$ & $\frac{\text { (Percent of Total) }}{64}$ & & $\begin{array}{l}\text { (Millions of } \\
\text { U.S. dollars) } \\
\end{array}$ & $\begin{array}{c}\text { (Percent of } \\
\text { total) }\end{array}$ & $\begin{array}{l}\text { (Millions of } \\
\text { U.S. dollars) } \\
\end{array}$ & $\begin{array}{c}\text { (Percent of } \\
\text { total) }\end{array}$ \\
\hline Thematic (and country) Trust Funds & 111 & 40 & Top 3 donors & 184 & 36 & 105 & 40 \\
\hline $\begin{array}{l}\text { Regional Technical Assistance } \\
\text { Centers }\end{array}$ & 129 & 47 & $\begin{array}{l}\text { Other (other donors and } \\
\text { international institutions) }\end{array}$ & 186 & 36 & 158 & 60 \\
\hline Regional Training Centers & 37 & 13 & Members (RTAC recipients & 141 & 28 & & \\
\hline Bilateral & 153 & 36 & & & & & \\
\hline Total & 429 & 100 & Total & 511 & 100 & 263 & 100 \\
\hline \multicolumn{3}{|c|}{$\begin{array}{l}\text { Source: CDIMS. } \\
\text { Note: Figures adjusted for RTC costs covered directly by the } \\
\text { hosts, which are not reflected in IMF accounts. }\end{array}$} & \multicolumn{5}{|c|}{$\begin{array}{l}\text { Source: CDIMS } \\
\text { 1/ Signed contributions and pledges for current cycle as of April } \\
30,2021 \text {. }\end{array}$} \\
\hline
\end{tabular}

10. Risks: During the pandemic, staff continued to manage funding risks related to externally financed $C D$.

- The COVID-19 Crisis CD Initiative was launched with a target of $\$ 100$ million, and commitments to date of about $\$ 36$ million. With partners' support, this new initiative is designed to allow funds to be allocated flexibly to address urgent $C D$ needs related to the pandemic. We also continue to promote flexibility within our existing vehicles.

- In addition, pursuing broader and more sustained partnerships remains a key objective in fundraising. More diversified partnerships will reduce dependence on large contributors as shortfalls from one partner can be more easily offset by the others. Longer and more strategic partnerships provide greater funding certainty over the medium term.

- As customary practice, staff reduce operational risks by securing financing upfront before planning CD delivery. Moreover, all CD projects or programs have built-in degrees of flexibility to allow adjustments, so work programs can be adjusted in case of a funding shortfall. 


\section{Annex III. Statistical Tables}

Annex Table 3.1 Gross Fund- and Externally Financed Spending Estimates by Output, FY18-211/

(Millions of FY21 U.S. dollars, support and governance costs allocated across outputs)

\begin{tabular}{|c|c|c|c|c|c|c|c|c|}
\hline & \multicolumn{4}{|c|}{ Millions of FY 21 U.S. dollars } & \multicolumn{4}{|c|}{ Percent of total } \\
\hline & FY 18 & FY19 & FY20 & FY21 & FY 18 & FY19 & FY20 & FY21 \\
\hline Total & 1,407 & 1,414 & 1,382 & 1,268 & 100.0 & 100.0 & 100.0 & 100.0 \\
\hline Multilateral surveillance & 280 & 266 & 265 & 277 & 19.9 & 18.8 & 19.2 & 21.8 \\
\hline Global economic analysis & 133 & 128 & 125 & 127 & 9.5 & 9.1 & 9.0 & 10.0 \\
\hline WEO & 18 & 18 & 19 & 19 & 1.3 & 1.2 & 1.4 & 1.5 \\
\hline GFSR & 17 & 15 & 14 & 16 & 1.2 & 1.0 & 1.0 & 1.3 \\
\hline General research & 39 & 40 & 39 & 39 & 2.8 & 2.8 & 2.8 & 3.1 \\
\hline General outreach & 59 & 56 & 52 & 52 & 4.2 & 4.0 & 3.8 & 4.1 \\
\hline Support and Inputs to Multilateral Forums and Consultations & 24 & 24 & 23 & 21 & 1.7 & 1.7 & 1.7 & 1.7 \\
\hline Multilateral consultations & 6 & 4 & 4 & 4 & 0.4 & 0.3 & 0.3 & 0.3 \\
\hline Support and Inputs to multilateral forums & 18 & 20 & 19 & 18 & 1.3 & 1.4 & 1.3 & 1.4 \\
\hline Tools to prevent and resolve systemic crises & 79 & 70 & 74 & 84 & 5.6 & 5.0 & 5.3 & 6.6 \\
\hline Analysis of vulnerabilities and imbalances & 22 & 20 & 24 & 27 & 1.5 & 1.4 & 1.7 & 2.2 \\
\hline Other cross cutting analysis & 51 & 45 & 44 & 49 & 3.6 & 3.2 & 3.2 & 3.9 \\
\hline Fiscal Monitor & 7 & 5 & 5 & 7 & 0.5 & 0.4 & 0.4 & 0.5 \\
\hline Regional approaches to economic stability & 45 & 44 & 44 & 45 & 3.2 & 3.1 & 3.2 & 3.6 \\
\hline REOs & 20 & 20 & 20 & 19 & 1.4 & 1.4 & 1.5 & 1.5 \\
\hline Surveillance of regional bodies & 8 & 8 & 7 & 8 & 0.6 & 0.6 & 0.5 & 0.6 \\
\hline Other regional projects & 16 & 16 & 17 & 18 & 1.1 & 1.1 & 1.2 & 1.4 \\
\hline Oversight of global systems & 146 & 149 & 151 & 154 & 10.4 & 10.6 & 10.9 & 12.1 \\
\hline Development of international financial architecture & 42 & 48 & 55 & 50 & 3.0 & 3.4 & 3.9 & 3.9 \\
\hline Work with FSB and other international bodies & 8 & 7 & 7 & 7 & 0.5 & 0.5 & 0.5 & 0.6 \\
\hline Other work on monetary, financial, and capital markets issues & 35 & 41 & 48 & 43 & 2.5 & 2.9 & 3.5 & 3.4 \\
\hline Data transparency & 43 & 40 & 37 & 40 & 3.0 & 2.9 & 2.7 & 3.1 \\
\hline Statistical information/data & 34 & 32 & 28 & 29 & 2.4 & 2.2 & 2.0 & 2.3 \\
\hline Statistical manuals & 2 & 2 & 2 & 5 & 0.2 & 0.2 & 0.2 & 0.4 \\
\hline Statistical methodologies & 6 & 6 & 7 & 5 & 0.4 & 0.5 & 0.5 & 0.4 \\
\hline The role of the Fund & 61 & 61 & 59 & 65 & 4.3 & 4.3 & 4.3 & 5.1 \\
\hline Development and review of Fund policies and facilities excl. PRGT and GRA & 27 & 28 & 25 & 28 & 2.0 & 1.9 & 1.8 & 2.2 \\
\hline Development and review of Fund policies and facilities - PRGT & 12 & 14 & 15 & 14 & 0.8 & 1.0 & 1.1 & 1.1 \\
\hline Development and review of Fund policies and facilities - GRA & 9 & 8 & 9 & 11 & 0.7 & 0.6 & 0.6 & 0.9 \\
\hline Quota and voice & 7 & 7 & 6 & 5 & 0.5 & 0.5 & 0.4 & 0.4 \\
\hline SDR issues & 5 & 4 & 4 & 7 & 0.4 & 0.3 & 0.3 & 0.5 \\
\hline Bilateral surveillance & 344 & 355 & 320 & 253 & 24.4 & 25.1 & 23.2 & 20.0 \\
\hline Assessment of economic policies and risks & 300 & 308 & 283 & 232 & 21.3 & 21.8 & 20.5 & 18.3 \\
\hline Article IV consultations & 227 & 235 & 210 & 157 & 16.1 & 16.6 & 15.2 & 12.4 \\
\hline Other bilateral surveillance & 73 & 73 & 74 & 75 & 5.2 & 5.2 & 5.3 & 5.9 \\
\hline Financial soundness evaluations - FSAPs/OFCs & 34 & 38 & 30 & 16 & 2.4 & 2.7 & 2.2 & 1.3 \\
\hline Standards and Codes evaluations & 9 & 9 & 7 & 6 & 0.7 & 0.6 & 0.5 & 0.4 \\
\hline ROSCs & 1 & 1 & 0 & 0 & 0.1 & 0.1 & 0.0 & 0.0 \\
\hline AML/CFT & 3 & 2 & 2 & 1 & 0.2 & 0.2 & 0.1 & 0.1 \\
\hline GDDS/SDDS & 6 & 6 & 4 & 4 & 0.4 & 0.4 & 0.3 & 0.3 \\
\hline Lending (incl. non-financial instruments) & 176 & 184 & 206 & 235 & 12.5 & 13.0 & 14.9 & 18.5 \\
\hline Arrangements supported by Fund resources & 152 & 138 & 167 & 206 & 10.8 & 9.8 & 12.1 & 16.2 \\
\hline Programs and precautionary arrangements supported by general resources & 74 & 71 & 93 & 113 & 5.3 & 5.0 & 6.8 & 8.9 \\
\hline Programs supported by PRGT resources & 78 & 67 & 74 & 93 & 5.6 & 4.8 & 5.4 & 7.4 \\
\hline Non-financial instruments and debt relief $2 /$ & 24 & 45 & 39 & 29 & 1.7 & 3.2 & 2.8 & 2.3 \\
\hline Capacity development & 429 & 432 & 401 & 330 & 30.5 & 30.5 & 29.0 & 26.0 \\
\hline Technical assistance & 361 & 362 & 337 & 284 & 25.6 & 25.6 & 24.4 & 22.4 \\
\hline Training & 69 & 70 & 65 & 46 & 4.9 & 4.9 & 4.7 & 3.6 \\
\hline Miscellaneous 3/ & 30 & 28 & 36 & 19 & 2.1 & 2.0 & 2.6 & 1.5 \\
\hline Reconciliation item 4/ & 2 & 0 & $\mathbf{0}$ & $\mathbf{0}$ & 0.1 & - & - & - \\
\hline
\end{tabular}

Source: OBP, Analytic Costing and Estimation System (ACES).

1/ Support and governance costs are allocated to outputs.

2/ Includes Post Program Monitoring (PPM), Policy Support Instruments (PSI), Staff Monitored Program (SMP), Near Programs, Ex-Post Assessments (EPA), Multilateral Debt Relief Initiative-I (MDRI-I), MDRI-II, Heavily Indebted Poor Countries (HIPC), Joint Staff Advisory Note (JSAN), Post Catastrophe Debt Relief (PCDR), Catastrophe Containment Relief Trust (CCRT), and trade integration mechanisms

${ }^{3 /}$ The "Miscellaneous" classification includes expenditures that currently cannot be properly allocated to specific outputs within the ACES model. Difference to FTC allocation represents mapping of direct departmental costs to IMF governance.

4/ Reconciliation to gross administrative expenditures as per the Fund's financial system. 
Annex Table 3.2. Gross Administrative Resources by Thematic Categories,

FY20-21

(Millions of FY21 U.S. dollars)

\begin{tabular}{|c|c|c|c|c|c|}
\hline & \multirow[t]{3}{*}{ FY 20} & \multicolumn{4}{|c|}{ FY 21} \\
\hline & & \multicolumn{3}{|c|}{ Budget } & \multirow[b]{2}{*}{ Outturn } \\
\hline & & $\begin{array}{l}\text { Structural } \\
\text { Resources }\end{array}$ & $\begin{array}{l}\text { Transitional } \\
\text { Resources }\end{array}$ & Total & \\
\hline Gross Expenditures & 1,382 & 1,429 & 38 & 1,467 & 1,268 \\
\hline Country operations & 595 & 655 & 12 & 667 & 503 \\
\hline Lending & 127 & 152 & 5 & 157 & 142 \\
\hline Surveillance & 203 & 211 & 5 & 216 & 159 \\
\hline$C D$ - Fund-financed $1 /$ & 93 & 86 & 2 & 88 & 84 \\
\hline$C D$ - Externally financed $2 /$ & 172 & 206 & & 206 & 118 \\
\hline Multilateral surveillance, analytics and policy work & 277 & 221 & 6 & 227 & 276 \\
\hline Fund governance and membership and Fund finances & 125 & 196 & 3 & 199 & 117 \\
\hline Internal support 3/ & 350 & 321 & 17 & 338 & 347 \\
\hline Miscellaneous 4/ & 36 & 25 & & 25 & 25 \\
\hline Contingency & & 11 & & 11 & \\
\hline Receipts & 204 & 243 & & & 142 \\
\hline Net Expenditures & 1,178 & 1,186 & 38 & 1,224 & 1,126 \\
\hline Carry forward & & 55 & & 55 & \\
\hline Total Available Resources & 1,178 & 1,241 & & 1,279 & 1,126 \\
\hline
\end{tabular}

Source: OBP estimates, Analytic Costing and Estimation System (ACES).

${ }^{1}$ CD Fund-financed reflects CD Direct Delivery only, residual is reflected mainly in internal support and wide category of multilateral surveillance, analytics and policy work.

${ }^{2} \mathrm{CD}$ - Externally financed includes management and administration activities.

${ }^{3}$ Governance and membership encompasses work supporting the Board of Governors, the Executive Board, Management, and internal functions such as risk management and internal audit; it also covers work on quota and voice.

4 "Miscellaneous" classification covers expenditures that currently cannot be allocated to specific outputs within the ACES model. 
Annex Table 3.3. Total Administrative Expenditures: Budgets and Outturn, FY11-21

(Millions of U.S. dollars, except where indicated otherwise)

\begin{tabular}{|c|c|c|c|c|c|c|c|c|}
\hline \multirow[t]{2}{*}{$\begin{array}{l}\text { Financial } \\
\text { Year }\end{array}$} & \multirow[t]{2}{*}{ Budget 1/ } & \multirow[t]{2}{*}{ Outturn 2/3/ } & \multicolumn{2}{|c|}{$\begin{array}{c}\text { Outturn to Budget } \\
\text { Difference }\end{array}$} & \multicolumn{2}{|c|}{$\begin{array}{c}\text { Budget to Budget } \\
\text { Difference }\end{array}$} & \multicolumn{2}{|c|}{$\begin{array}{c}\text { Outturn to Outturn } \\
\text { Difference }\end{array}$} \\
\hline & & & Amount & Percent & Amount & Percent & Amount & Percent \\
\hline \multicolumn{9}{|c|}{ A. Net Budget } \\
\hline 2011 & 953 & 917 & -36 & -3.8 & 22 & 2.3 & 54 & 6.2 \\
\hline 2012 & 985 & 947 & -38 & -3.9 & 32 & 3.3 & 30 & 3.2 \\
\hline 2013 & 997 & 948 & -50 & -5.0 & 13 & 1.3 & 1 & 0.1 \\
\hline 2014 & 1,007 & 988 & -19 & -1.8 & 9 & 0.9 & 40 & 4.3 \\
\hline 2015 & 1,027 & 1,010 & -17 & -1.7 & 20 & 2.0 & 21 & 2.2 \\
\hline 2016 & 1,052 & 1,038 & -13 & -1.3 & 25 & 2.4 & 29 & 2.8 \\
\hline 2017 & 1,072 & 1,066 & -6 & -0.6 & 21 & 2.0 & 28 & 2.7 \\
\hline 2018 & 1,104 & 1,099 & -5 & -0.5 & 31 & 2.9 & 32 & 3.0 \\
\hline 2019 & 1,135 & 1,131 & -4 & -0.3 & 32 & 2.9 & 33 & 3.0 \\
\hline 2020 & 1,158 & 1,150 & -8 & -0.7 & 23 & 2.1 & 19 & 1.7 \\
\hline 2021 & 1,186 & 1,126 & -60 & -5.1 & 28 & 2.4 & -24 & -2.1 \\
\hline \multicolumn{9}{|c|}{ B. Gross Budget } \\
\hline 2011 & 1,075 & 1,021 & -54 & -5.0 & 43 & 4.2 & 71 & 7.4 \\
\hline 2012 & 1,123 & 1,082 & -41 & -3.7 & 48 & 4.5 & 61 & 6.0 \\
\hline 2013 & 1,159 & 1,102 & -57 & -4.9 & 35 & 3.2 & 20 & 1.8 \\
\hline 2014 & 1,186 & 1,149 & -37 & -3.2 & 27 & 2.3 & 47 & 4.3 \\
\hline 2015 & 1,224 & 1,177 & -46 & -3.8 & 38 & 3.2 & 29 & 2.5 \\
\hline 2016 & 1,247 & 1,215 & -33 & -2.6 & 24 & 1.9 & 38 & 3.2 \\
\hline 2017 & 1,273 & 1,255 & -18 & -1.4 & 25 & 2.0 & 40 & 3.3 \\
\hline 2018 & 1,315 & 1,309 & -6 & -0.4 & 42 & 3.3 & 54 & 4.3 \\
\hline 2019 & 1,371 & 1,346 & -26 & -1.9 & 56 & 4.3 & 37 & 2.8 \\
\hline 2020 & 1,397 & 1,350 & -48 & -3.4 & 26 & 1.9 & 4 & 0.3 \\
\hline 2021 & 1,429 & 1,268 & -161 & -11.3 & 32 & 2.3 & -82 & -6.1 \\
\hline
\end{tabular}

Source: OBP.

Note: Figures may not add to total due to rounding.

${ }^{1}$ Excludes carry forward funds from previous year of $\$ 34.4$ million (FY12), \$40.6 million (FY13), \$41.9 million

(FY14), \$41.7 million (FY15), \$42.5 million (FY16), \$43.2 million (FY17), \$44.3 million (FY18), \$45.6 million

(FY19), \$46.9 million (FY20), and \$55.2 million (FY21).

${ }^{2}$ Includes contributions to the Staff Retirement Plan (SRP) service credit buyback program of $\$ 8$ million in

FY05, \$10 million in FY06, \$20.5 million in FY07, and \$2.1 million in FY08 and a one-off voluntary contribution of \$12 million in FY09.

${ }^{3}$ Includes one-off supplementary contributions to the Retired Staff Benefit Investment Account (RSBIA) of \$27 million in FY09, $\$ 30$ million in FY10; $\$ 45$ million in FY11; $\$ 30$ million in FY12; $\$ 12$ million in FY13;

$\$ 8$ million in FY16; and \$2 million in FY17. 


\begin{tabular}{|c|c|c|c|c|}
\hline \multicolumn{5}{|c|}{$\begin{array}{c}\text { Annex Table 3.4. Total Fund Employment, FY18-21 } \\
\text { (Full-time Equivalents, FTEs) }\end{array}$} \\
\hline & FY 18 & FY 19 & FY 20 & FY 21 \\
\hline Total Fund employment & 3,881 & 3,899 & 3,912 & 3,981 \\
\hline Regular and term staff & 2,923 & 2,958 & 2,982 & 3,021 \\
\hline Fund-financed & 2,836 & 2,865 & 2,886 & 2,928 \\
\hline \multicolumn{5}{|l|}{ Of which: } \\
\hline Independent Evaluation Office (IEO) & 15 & 15 & 15 & 15 \\
\hline Office of Executive Directors (OED) & 247 & 247 & 249 & 247 \\
\hline Externally financed & 87 & 93 & 96 & 94 \\
\hline Expert and Contractual Staff 1/ & 958 & 941 & 930 & 959 \\
\hline Fund-financed & 586 & 588 & 599 & 651 \\
\hline Externally financed & 372 & 353 & 330 & 309 \\
\hline
\end{tabular}


Annex Table 3.5. Departmental Business Travel and Seminar Expenditures, FY19-21 (Millions of U.S. dollars)

\begin{tabular}{lrrr}
\hline & FY 19 $1 /$ & FY 20 & FY 21 \\
\hline By type of cost & $\mathbf{1 1 6}$ & $\mathbf{8 6}$ & $\mathbf{2}$ \\
Transportation & 68 & 51 & 1 \\
Per diem & 48 & 35 & 0 \\
By type of financing & $\mathbf{1 1 6}$ & $\mathbf{8 6}$ & $\mathbf{2}$ \\
Fund-financed & 70 & 50 & 2 \\
txternally tinanced & 46 & 36 & 0 \\
By department & $\mathbf{1 1 6}$ & $\mathbf{8 6}$ & $\mathbf{2}$ \\
Area & 29 & 22 & 1 \\
Functional CD & 65 & 50 & 0 \\
Functional non-CD & 6 & 4 & 0 \\
Support and Governance & 9 & 5 & 0 \\
OED and IEO & 7 & 5 & 0 \\
Memorandum item: & & & \\
In percent of total gross expenditures & 8.6 & 6.4 & 0.1 \\
\hline OBP. & & & \\
\hline
\end{tabular}


Annex Table 3.6. Capital Expenditures, FY15-21

(Millions of U.S. dollars)

\begin{tabular}{|c|c|c|c|c|c|c|c|c|}
\hline & Formula Key & Facilities & $\begin{array}{l}\text { Information } \\
\text { Technology }\end{array}$ & HQ2 & $\begin{array}{c}\text { HQ1 } \\
\text { Renewal }\end{array}$ & $\begin{array}{l}\text { Concordia } \\
\text { Renovation }\end{array}$ & & $\begin{array}{l}\text { Total } \\
\text { Capital }\end{array}$ \\
\hline \multicolumn{9}{|l|}{ FY 15} \\
\hline New appropriations & (11) & 22.0 & 29.8 & & 0.0 & 0.6 & $3 /$ & 52.4 \\
\hline Total funds available & $(12)=(10)+(11)$ & 41.2 & 42.6 & & 313.1 & 0.6 & & 397.4 \\
\hline Expenditures & (13) & 10.5 & 29.3 & & 95.7 & 0.3 & & 135.8 \\
\hline Lapsed funds $1 /$ & $(14)$ & 0.6 & 0.3 & & 0.0 & 0.3 & & 1.2 \\
\hline Remaining funds $2 /$ & $(15)=(12)-(13)-(14)$ & 30.1 & 12.9 & & 217.4 & 0.0 & & 260.4 \\
\hline \multicolumn{9}{|l|}{ FY 16} \\
\hline New appropriations & (16) & 14.4 & 27.7 & & 132.04 & & & 174.1 \\
\hline Total funds available & $(17)=(15)+(16)$ & 44.5 & 40.6 & & 349.4 & & & 434.5 \\
\hline Expenditures & (18) & 14.6 & 25.8 & & 90.1 & & & 130.5 \\
\hline Lapsed funds $1 /$ & (19) & 0.4 & 0.1 & & 0.0 & & & 0.6 \\
\hline Remaining funds $2 /$ & $(20)=(17)-(18)-(19)$ & 29.4 & 14.7 & & 259.2 & & & 303.4 \\
\hline \multicolumn{9}{|l|}{ FY 17} \\
\hline New appropriations & (21) & 32.5 & 28.0 & & 0.0 & & & 60.5 \\
\hline Total funds available & $(22)=(20)+(21)$ & 62.0 & 42.7 & & 259.2 & & & 363.9 \\
\hline Expenditures & (23) & 17.9 & 27.9 & & 76.3 & & & 122.1 \\
\hline Lapsed funds $1 /$ & (24) & 5.4 & 0.2 & & 0.0 & & & 5.6 \\
\hline Remaining funds $2 /$ & $(25)=(22)-(23)-(24)$ & 38.7 & 14.6 & & 182.9 & & & 236.2 \\
\hline \multicolumn{9}{|l|}{ FY 18} \\
\hline New appropriations & (26) & 31.4 & 35.0 & & 0.0 & & & 66.4 \\
\hline Total funds available & $(27)=(25)+(26)$ & 70.1 & 49.6 & & 182.9 & & & 302.6 \\
\hline Expenditures & (28) & 22.3 & 31.4 & & 62.3 & & & 116.0 \\
\hline Lapsed funds $1 /$ & (29) & 0.3 & 0.0 & & 0.0 & & & 0.3 \\
\hline Remaining funds & $(30)=(27)-(28)-(29)$ & 47.4 & 18.2 & & 120.6 & & & 186.3 \\
\hline \multicolumn{9}{|l|}{ FY 19} \\
\hline New appropriations & (31) & 35.5 & 35.9 & & 0.0 & & & 71.4 \\
\hline Total funds available & $(32)=(30)+(31)$ & 82.8 & 54.1 & & 120.6 & & & 257.5 \\
\hline Expenditures & (33) & 28.7 & 30.9 & & 81.6 & & & 141.2 \\
\hline Lapsed funds $1 /$ & (34) & 5.9 & 0.0 & & 0.0 & & & 5.9 \\
\hline Remaining funds & $(35)=(27)-(28)-(29)$ & 48.1 & 23.2 & & 39.0 & & & 110.4 \\
\hline \multicolumn{9}{|l|}{ FY 20} \\
\hline New appropriations & (36) & 40.8 & 45.0 & & 0.0 & & & 85.8 \\
\hline Total funds available & $(37)=(35)+(36)$ & 88.9 & 68.2 & & 39.0 & & & 196.2 \\
\hline Expenditures & (38) & 41.8 & 42.2 & & 22.8 & & & 106.8 \\
\hline Lapsed funds $1 /$ & (39) & 1.8 & 0.0 & & 0.0 & & & 1.8 \\
\hline Remaining funds & $(40)=(37)-(38)-(39)$ & 45.4 & 26.0 & & 16.2 & & & 87.6 \\
\hline \multicolumn{9}{|l|}{ FY 21} \\
\hline New appropriations & $(41)$ & 42.4 & 56.3 & & 0.0 & & & 98.7 \\
\hline Total funds available & $(42)=(40)+(41)$ & 87.8 & 82.3 & & 16.2 & & & 186.3 \\
\hline Expenditures & (43) & 25.7 & 49.7 & & 1.5 & & & 76.9 \\
\hline Lapsed funds 1/ & (44) & 2.5 & 0.0 & & 0.0 & & & 2.5 \\
\hline Remaining funds 2 / & $(45)=(42)-(43)-(44)$ & 59.6 & 32.6 & & 14.7 & & & 106.9 \\
\hline
\end{tabular}

Sources: OBP and Corporate Services and Facilities Department and Information Technology Department.

${ }^{1 /}$ Figures reflect funds that were not spent within the three-year appropriation period; e.g., FY16 appropriated funds lapsed at the end of FY18.

2/ Figures reflect the unspent amount of the budget appropriation in the period concerned. Those funds can be used for authorized projects in the remaining period(s).

${ }^{3 /}$ Unspent Concordia funds appropriated in FY12 expired at the end of FY14 with the exception of \$0.6 million that was specifically reappropriated for FY15 to complete the remaining work under the project.

${ }^{4 / A d d i t i o n a l ~ a p p r o p r i a t i o n s ~ w e r e ~ a p p r o v e d ~ f o r ~ t h e ~ H Q 1 ~ R e n e w a l ~ P r o g r a m ~ d u r i n g ~ F Y 16 . ~}$ 